\title{
Challenges and opportunities for a successful mining industry in the future
}

\author{
António Mateus ${ }^{(1)}$ and Luís Martins ${ }^{(2)}$ \\ (1) Dept. Geologia \& IDL, Faculdade de Ciências da Universidade de Lisboa, Ed. C6, Piso 4, Campo Grande, \\ 1749-016 Lisboa, Portugal \\ (2) ASSIMAGRA, Rua Aristides de Sousa Mendes n³B, 1600-412 Lisboa, Portugal. \\ Imartins@assimagra.pt
}

\begin{abstract}
Modern models of sustainable economic growth are metal-intensive and will not be successful in the future unless a continuous supply of mineral-derived products is ensured. Despite this being logical, there is still a significant reluctance regarding mineral exploration and mining activities, often reflected in: (i) unfavourable public opinions; and (ii) absence of political measures or continuity of agendas that actually appreciate the way minerals are produced and the players directly or indirectly involved in this production. To succeed, the mining industry will have to (re)define its strategy and find innovative approaches to old problems and clearly demonstrate that mineral products can be efficiently delivered to support global development and assist suitable paths to welfare and quality of life, thus also providing real value to all concerned. In this study we give a concise review of the main challenges posed to the mining industry, and also indicate the most relevant opportunities and advance some proposals to constructively face the identified weaknesses and threats. The fundamental outcome is that the long-term balance between supply and demand of mineral products requires concerted actions on different fronts aiming: (i) the safeguarding of known resources; (ii) high-quality (scientifically and technologically driven) exploration surveys; (iii) improvements in mining and mineral transformation/ beneficiation; (iv) advances in consistent combinations of primary and secondary sources of raw materials, along with higher concerns on their judicious use; (v) effective and stable mining policies; and (vi) new insights on the role played by the mining industry through fruitful dialogues with society in general.
\end{abstract}

Keywords: circular economy, criticality, challenges for the mining industry, resources for the future, sustainability.

\section{Desafíos y oportunidades para un futuro de éxito en la industria minera}

\section{RESUMEN}

Los modelos actuales de crecimiento económico sostenible resultan intensivos en el uso de metales, y no tendrán éxito en el futuro si no se asegura un suministro continuado de los productos derivados de los minerales. Aparte de esta evidencia, existe todavía un significativo rechazo relacionado con la exploración mineral y las actividades mineras, a menudo reflejado en: (i) una opinión pública desfavorable; y (ii) la ausencia de medidas políticas o una continuidad en las agendas que valoren la manera en que se producen los minerales y a los actores directa o indirectamente envueltos en esta producción. Para tener éxito, la industria minera deberá (re)definir su estrategia y encontrar acercamientos innovadores a los antiguos problemas, demostrando claramente que los productos minerales pueden ser suministrados eficientemente para mantener del desarrollo global y proporcionar rutas adecuadas al bienestar y la calidad de vida, proporcionando a su vez un valor real a todos los interesados. En este trabajo se realizará una revisión concisa de los principales desafíos que se encuentra la industria minera, señalando también las oportunidades más relevantes y avanzando algunas propuestas para afrontar de manera constructiva las debilidades y amenazas identificadas. El resultado principal es que el equilibrio en el largo plazo, entre suministro y demanda de productos minerales, requiere acciones concertadas en diferentes frentes apuntando a: (i) la salvaguarda de los recursos conocidos; (ii) estudios geológicos de alta calidad (dirigidos científica y tecnológicamente); (iii) mejoras en minería y transformación/beneficio; (iv) avances en la combinación de materias primas de origen primario y secundario, así como una mayor preocupación en su empleo; (v) una política minera efectiva y estable; y (vi) una nueva percepción del papel jugado por la industria minera mediante un diálogo fructífero con la sociedad en general.

Palabras clave: criticidad, desafíos de la industria minera, economía circular, recursos para el futuro, sostenibilidad. 


\section{Introduction}

Much has been written recently about the past, present and future relevance of industrial minerals and metals for society (e.g. Krausmann et al., 2009; Mason et al., 2011; Arndt and Ganino, 2012; Bloodworth and Gunn, 2012; Graedel and Erdmann, 2012; Vidal et al., 2013; Lusty and Gunn, 2014; PatiñoDouce, 2016; Meinert et al., 2016; Arndt et al., 2017; Fortier et al., 2018; Christmann, 2018). Even so, instead of recognizing the important role played by the mining industry over time and its invaluable contribution to the design of future development policies, many persuasive sectors of modern society persist in the idea of a technologically outdated and environmentally aggressive industry which is to a great extent unnecessary. This is a biased and significantly groundless idea that has been consolidated throughout several decades, and is difficult to contradict because other arguments rather than technical ones should be used. In fact, the generalized levels of distrust that subsist in many regions about all kinds of mineral exploration and mining activities are a consequence of a spiral of sensations resulting from the joining historical real facts and biased opinions together, which means that the easier current position in many social/political circles is to be against mining, even without offering a rational explanation to justify this. However, this behaviour generates a challenging paradox: society requires more and more of certain types of mineral-derived products; we consume them at increasing rates; but we neither appreciate the way in which these goods are produced nor the industrial activities involved in their production. Therefore, a cultural change is needed to definitely overcome the social rejection of activities related to the mining industry, particularly felt in some economically advanced countries. Some premises of such rejection are not unwarranted, but the modern mining industry has to develop new ways to communicate, proving that serious errors which were made in the past are no longer acceptable and that the industry will focus on implementing transparent measures towards a fully responsible industrial activity. Currently, much work has to be done to convince all the political actors of the need to ensure coherent and long-term stable policies regarding the access and management of mineral resources. It is also essential to demonstrate the importance of having continuous public investment in scientific research, technological and innovation programmes aimed at the expansion of present-day geological knowledge on mineral resources, as well as new methodologies to efficiently use them. It can be said that these principles are valid for many other economic sectors, once the necessary adaptations have been made. However, there are few long-standing sectors that remain as critical to the future development of society as the mining industry, which increasingly depends on the stability of long-term policies (e.g. Tilton et al., 2018) and intensive knowledge to minimize the high-risk and the intensive capital that it needs to run. In this context, what are the priority issues and fields of action that will make the most difference and who will drive the change process?

Five main inter-related issues can be identified, all of them involving innovation and impacting public awareness in multiple ways. These are: (i) the endless discussion about the long-term availability of mineral resources; (ii) the future evolution of the demand/supply balance and its implications on mineral production; (iii) the rising pressures on mining exploitation and mineral transformation triggered by the social and environmental demands of sustainable development; (iv) the real usefulness of static critical analysis for mining planning; and $(v)$ the role of mineral production in reliable circular economy models. The first three issues include matters that already put additional pressure on regular endeavours carried out by the mining industry worldwide, requiring an active search for new approaches to familiar practices that may determine its long-term success. The last two issues represent critical challenges to the design of forthcoming policies and incentive measures where the mining industry must be really involved, being part of the solution and not of the problem, and contributing with proactive solutions. All these topics will be concisely reviewed further below, emphasizing the need for: (i) safeguarding the access to known mineral resources, in parity with other natural resources; (ii) identifying new resources; (iii) optimizing mining processes, from development to exploitation, processing, product delivery and waste management; and (iv) including primary and secondary mineral sources in material flows supporting realistic models of economic and technological growth in the future. The joint analysis of the challenges posed to mineral exploration and mining, subsequently integrated into the socio-economic and environmental concerns that regulate the current and emerging paradigms ruling new development policies, could be seen as inappropriate and/or ambitious. However, without successful exploration surveys there is no mineral exploitation or processing; and, in addition, without a long-lasting and secure supply of mineral-derived products many of the disruptive measures included in sustainable growth policies, that have recently been launched or were already announced as certain for the short term, 
will be at risk. So, the aforementioned issues are interdependent and should be assessed collectively.

\section{Long-term availability of mineral resources}

The historical evolution of global mineral production records a systematic net growth, despite various upand-down interchanges documenting successive economic cycles of variable extent (e.g. Mudd, 2007a, b:, Schodde, 2012; Humphreys, 2013; Sverdrup and Ragnasdöttir, 2014; Tilton and Guzmán, 2016; Mudd et al., 2017; Mudd and Jowitt, 2018). This general trend is expected to remain positive and high, possibly increasing for a large number of industrial minerals and metals, since the underlying demand from an expanding world population and emerging economies will continue to rise (see Section 3). So, is it legitimate to ask how long it will be possible to main current consumption rates? Or, in a more polite way: will there be enough resources to support the anticipated production increase? Similar questions dealing with the threat of physical depletion and the availability of resources for the future have been recurrently addressed in many studies (e.g. Govett and Govett, 1972; Skinner, 1976; Cook, 1976; Tilton, 2003, 2006; Yaksic and Tilton, 2009; Rosenau-Tornow et al., 2009; Gunn, 2011; Shodde, 2010a, 2017c; Crowson, 2011; Prior et al., 2012; Henckens et al., 2009; Sverdrup and Ragnasdóttir, 2014; Calvo et al., 2016; Northey et al., 2018; Tilton et al., 2018). However, despite the simple and convincing logic behind the "fixed stock paradigm" (strongly influenced by the Malthusian perspective), the main causes that determine mineral production are related to externalities and other factors directly or indirectly involved in the "opportunity cost paradigm". In other words, long-run shortages in mineral production are not triggered by physical depletion; rather they are historically influenced by complex interactions of multiple geo-political and/or economic reasons that shape market prices, confine access to known resources, prevent mining and mineral processing or even restrain international fair trading.

Notwithstanding the constraints imposed by geopolitical and/or economic factors, the long-term availability of primary mineral resources will always depend on the extant knowledge at each moment on how much exists and where. In this regard, a simple approach to the problem can be envisaged by comparing the results gathered from: (i) the assessment of the total mass of an element $i$ existing in the initial $1 \mathrm{~km}$ depth of the upper continental crust $\left(M_{i}^{\mu c}\right)$ according to the algebraic operation $A_{i}^{u c} \times M^{u c}{ }_{1 \mathrm{~km} \text { depth }}$ where $A_{i}^{u c}$ stands for the elemental abundance in the upper crust (Rudnick and Gao, 2014) and $M^{\mu c}{ }_{1 \mathrm{~km} \mathrm{depth}}$ is the total mass of the uppermost crustal layer (i.e. $\approx$ $4.2 \times 10^{17} \mathrm{t}$ ); (ii) the estimation of the $M_{i}^{\text {uc }}$ fraction contained in known and potential resources $\left(=R_{i}^{\prime}\right)$, including past production, following the empirical functional relationship reported in Godinho (1982), i.e.

$$
R_{i}^{\prime}=10^{10.52} \times 10^{0.85 \log A_{i}^{U C}}
$$

and (iii) the computation of the total elemental mass theoretically concentrated in possible mineral resources hosted in that portion of upper crust $\left(=R_{i}\right)$, considering the variation in cut-off grades (from $\boldsymbol{X}_{i}^{\text {min }}$ to $X_{i}^{\text {max }}$ and the formulation given in Menaker (1978).

$$
R_{i}=10^{-2} b\left[\int_{\ln \left(x_{i}^{\min }\right)}^{\ln \left(x_{\max }^{\max }\right)} e^{-\left(\ln x_{i}\right)^{2} /\left(\ln x_{i}^{\max }-\ln x_{i}\right)} d \ln x_{i}\right] M_{1 k m \text { depth }}^{U C} A_{i}^{U C}
$$

where $b$ is an empirical constant valid for each element $i$. Taking into account the uncertainties involved in these calculations, $R_{i}^{\prime}$ and $R_{i}$ values are possibly under- or overestimated for $A_{i}^{u c}<1,000 \mathrm{ppm}$ and $A_{i}^{u c}$ $\geq 1,000 \mathrm{ppm}$, respectively, but both are significantly below $M_{i}^{\text {uc }}$ (Fig. 1A). Even so, $R_{i}^{\prime}$ values show good agreement with the range of variation gathered for the reserve base estimates $\left(=M_{i}^{R B}\right)$ provided by the USGS (2009), which are usually interpreted as the lower limit to the exploitable global resource. In this regard it should be noted that the best fit $\left(r^{2}=0.83\right)$ for the general co-variation between $M_{i}^{R B}$ and $A_{i}^{u c}\left[M_{i}^{R B} \approx \mathrm{C}\right.$ $\times 10^{6}\left(A_{i}^{\text {uc }}\right)^{0.734} ; 0.1<c<75$ ] is obtained when $\mathrm{c}=2.5$ (Fig. 1A).

According to the aforementioned approach, and despite the need for more robust information on the "mineable" resources worldwide, there is no firm evidence for imminent physical exhaustion. On the contrary, the internal consistency documented by the relationship $M_{i}^{\mu c}>R_{i}>M_{i}^{R B}\left(\approx R_{i}^{\prime}\right)$ indicates that there is plenty room for new discoveries in the initial $1 \mathrm{~km}$ depth of the upper continental crust, as illustrated in Figures $1 \mathrm{~B}$ and $\mathrm{C}$ for a large diversity of elements. Nonetheless, we must not forget that $R_{i}$ is not uniformly distributed in the crust and conditions for their possible exploitation will vary in time according to technological improvements, economics and many other modifying factors. Therefore, four main challenges emerge as fundamental to minimize potential shortages in mining production and concurrently ensure the long-term availability of mineral resources; in short, this means that significant work is 
A

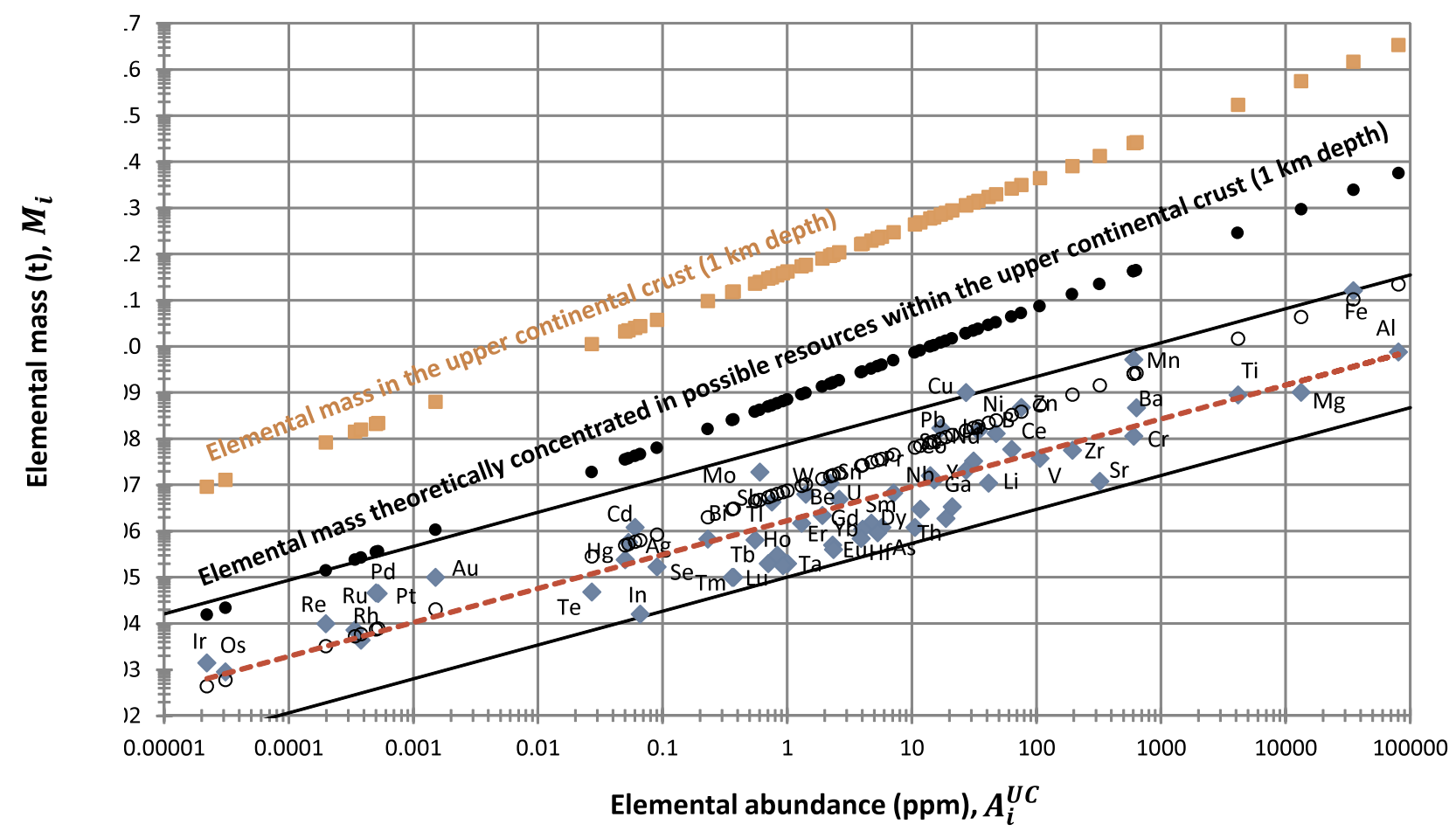

B
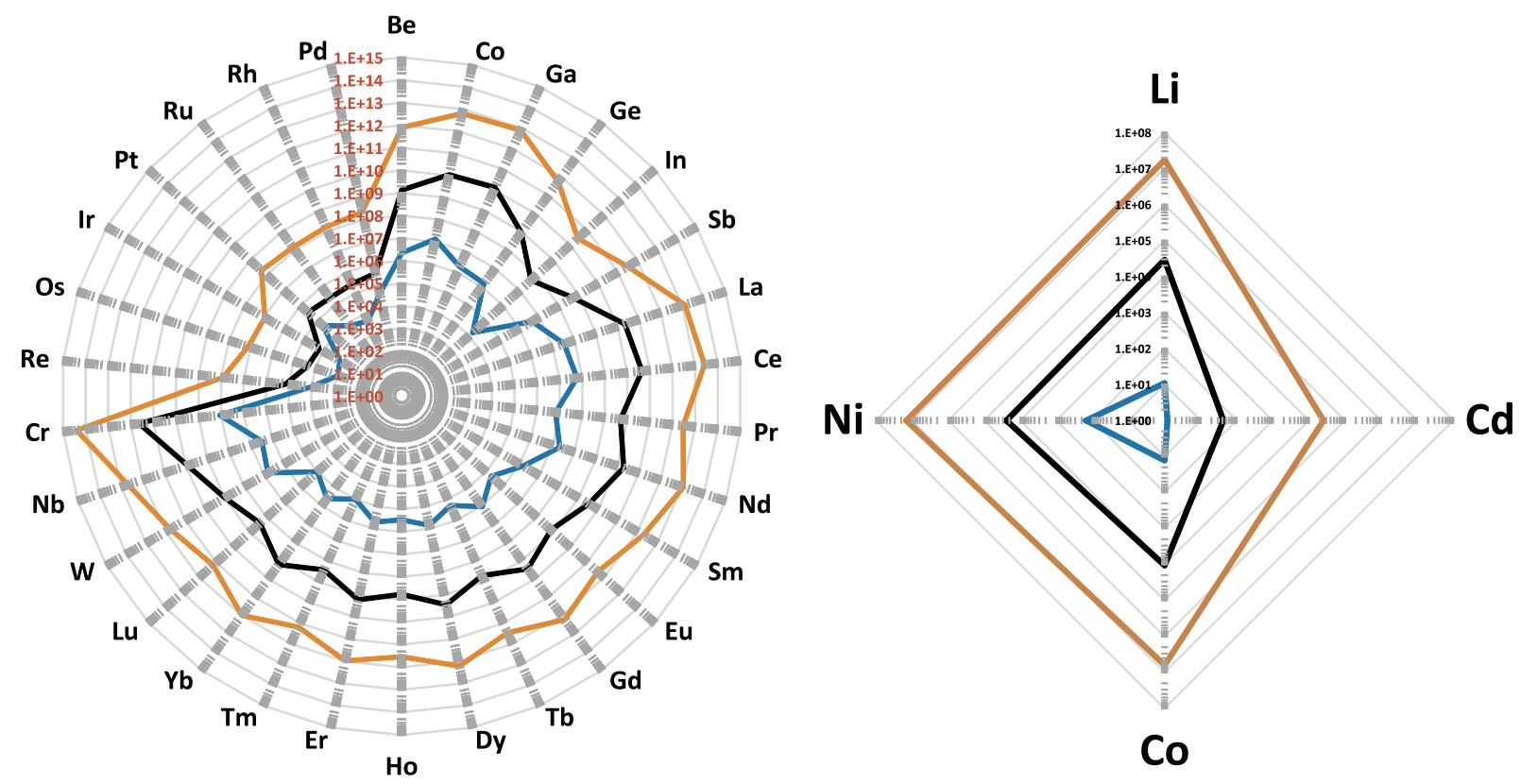
needed to: (i) safeguard the access to known resources and promising targets, conciliating goals and practices of mining planning with those of landuse management and planning; (ii) reduce the dependency on hegemonic producers, diversifying the number of players and the places where active mines can be feasible, through suitable mining development policies and long-lasting investments oriented to geo-scientific data improvements; (iii) continuously uphold high-quality mineral exploration endeavours, making use of cutting-edge tools and innovative prospective models; and (iv) increase the current knowledge on reserves based at a regional scale to better manage global resources and ensure both the anticipated short- to medium-range supply of minerals and metals and the opportunity of forthcoming generations decide on the access/use of those resources.

The first challenge, although logical and conceptually easily to overcame, encompasses a long series of practical difficulties for which there are no obvious solutions of universal application. In fact, reconciliation procedures between mining and land-use planning are not as common as they should be, often experiencing different types of blockage due to the absence of adequate regulations and/or the involvement of actors not aware enough of the subject. However, several theoretical and tangible advancements have been made in the last decade, including some proposals that may assist as guides to further developments (Owens, 1997; Cowell and Owens, 1998; Cowell and Murdoch, 1999; Evans et al., 2009; Wrighton et al., 2014; Allington et al., 2016; Mateus et al., 2017; Lopes et al., 2018). In other words, the first steps towards alternative solutions have been done; it is therefore necessary to continue the process, deep- ening the measures and refining the methodologies in accordance with the legal frameworks in force (or to be created) at regional, national or transnational levels.

The other three challenges are closely inter-related and will be addressed in the following sections. Yet a first highlight should be made in what concerns the remarkable achievements of the last 50 years on the delimitation of new mineral districts, discovering new types of deposits, and the implementation of innovative exploration technologies (e.g. Shodde, 2014a, b; $2017 a, b)$. Therefore, despite market fluctuations and many other adversities, the mining industry has revealed competences to react positively in the exploration field, so far delivering solutions to the demonstrated or anticipated needs at each stage of the global economic and technological development. Will it be prepared enough to maintain this record in the future? Are there any symptoms of concern?

\section{Future evolution of the demand/supply balance}

We live in a rapidly changing world where technological innovations of massive use follow one another at a speed never imagined. Concurrently, environmental concerns have gained consistency worldwide and increasing weight in the design of novel development policies that have gradually boosted the generalization of measures towards a low-C and more eco-efficient economy. Population growth has not slowed down either, putting additional pressure on productive processes to meet basic needs and ensure decent standards of living. Despite the strong asymmetries that persist in many regions of the world, all these trends have been contributing to an ever increasing

Figure 1. (A) Total elemental mass estimates $\left(M_{i}\right)$ as a function of the upper crustal abundance $\left(=A_{i}{ }^{u c}\right)$ reported in Rudnick and $G a o(2014)$. Brownish-yellow squares represent $M_{i} \mathrm{uc}, 1 \mathrm{~km}$ deth, black circles the $\mathrm{M}_{i}^{\mathrm{uc}}$ fraction contained in known and potential resources $\left(=\mathrm{R}_{i}^{\prime}\right)$, white circles the total elemental mass theoretically concentrated in possible mineral resources hosted in that portion of upper crust $\left(=\mathrm{R}_{\mathrm{i}}\right)$, and blue diamonds the reserve base values $\left(=\mathrm{M}_{\mathrm{i}}^{\mathrm{RB}}\right)$ provided by the USGS (2009). The amplitude of variation yielded by the general co-variation between $M_{i}^{R B}$ and $A_{i}{ }_{i} \mathrm{C}$ is bounded by the two black lines $\left[M_{i}^{R B} \approx c \times 10^{6}\left(A_{i}{ }^{\mathrm{UC}}\right)^{0.734} ; 0.1<c<75\right]$ while the best fit $\left(r^{2}=0.83\right.$; $\left.c=2.5\right)$ is indicated by the red dashed-line. $(B, C)$ Spider plots documenting the relationship $M_{i}{ }^{\mathrm{UC}}>R_{i}>M_{i}^{R B}$ (in $\left.t\right)$ for various elements (brownish-yellow, black and blue broken-lines, respectively), most of them vulnerable to supply disruptions but all fundamental to the consolidation and expansion of new technologies, as well as to support the ongoing revolution in energy (production and storage) and transportation (electric mobility). After Mateus $(2016,2017 b)$.

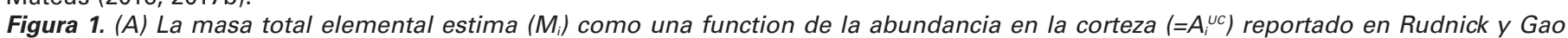
(2014). Los cuadrados de color marrón amarillento representan $M_{i}^{u c, 1 ~ k m ~ d e p t h, ~ l o s ~ c i ́ r c u l o s ~ n e g r o s ~ l a ~ f r a c c i o ́ n ~} M_{i}$ uc la fracción contenida en los recursos conocidos y potenciales $\left(=R_{i}^{\prime}\right)$, los círculos blancos la masa total elemental teóricamente concentrada en recursos minerales posibles ubicados en esa porción de la corteza superior $\left(=R_{i}\right)$, y los diamantes azules los valores de las reservas base $\left(=M_{i}^{R B}\right)$ proporcionadas por el USGS (2009). La amplitud de variación producida por la covariación entre $M_{i}^{R B}$ y $A_{i}^{u C}$ está limitada por las dos líneas negras $\left[M_{i}^{R B} \approx C \times 10^{6}\left(A_{i}^{\text {uc }}\right)^{0.734} ; 0.1<C<75\right]$ mientras que el mejor ajuste $\left(r^{2}=0.83 ; c=2.5\right)$ se indica mediante la línea discontinua roja. $(B, C)$ Los gráficos de araña documentan la relación $M_{i}{ }^{U C}>R_{i}>M_{i}^{R B}$ (en $t$ ) para varios elementos (líneas discontinuas de color amarillo parduzco, negro y azul, respectivamente), la mayoría de ellas vulnerables a las interrupciones del suministro, pero todas fundamental para la consolidación y expansión de nuevas tecnologías, así como para apoyar la revolución energética en curso (producción y almacenamiento) y transporte (movilidad eléctrica). Mateus (2016, 2017b). 
demand for metals and industrial minerals, as is clearly documented in numerous recent projections (e.g. Buchert et al., 2009; Mudd et al., 2013; de Boer and Lammertsma, 2013; Moss et al., 2013; Fizaine, 2013; Kavlak et al., 2015; Wellmer and Hagelüken, 2015; Nassar et al., 2015; Frenzel et al., 2015, 2016; Lovik et al., 2016). Will the mining industry be able to adjust its modus operandi to this rapid rate of change? Or, on the contrary, will it maintain its usual procedure, slowly regulating the priorities to new challenges and reacting circumstantially when market opportunities arise? The answer to these questions is of prime importance to suitably solve the main dilemma posed by "The Limits to Growth" theory (Meadows et al., 1972). In fact, according to the numerical model behind that theory, the economic system would collapse at some point if the exponential increase of consumption is not balanced with the resource availability (fixed or expanding at a rate well below the one needed to compensate the rise in consumption). This forecast, although logical, has been subjected to intense scrutiny since its publication, and the main argument used relies on the deficient allowance for technological innovation, which is factual, as demonstrated by the advances recorded in the last three decades. The same is true for mineral resources, considering the findings resultant from exploration endeavours (already mentioned in the previous section) and the improvements recorded in mining and processing/beneficiation (to be addressed in Section 5). Thus, how can we explain the results presented in Turner $(2008,2012,2014)$ demonstrating that, after all, the projections of Meadows et al. (1978) do not deviate as much from reality as many have claimed? As far as the outputs involving the mining industry are concerned, the explanation for this apparent inconsistency is given in several other studies focused on the performance of mineral exploration activities, namely regarding the record of net results (i.e. new findings and their intrinsic quality) and the associated expenditures, as follows.

The scenario resulting from four decades of "business as usual" (e.g. Turner, 2014) suggests that the capital required to find and extract harder-to-reach resources will soon become high enough to be no longer competitive with other (priority) investment needs. Accordingly, global resources will inevitable experience a significant depletion as there will be no financial conditions to support the discovery of new sources and/or launch in due time all the operations needed for their exploitation. In other words, the high depletion rates to known resources only barely will be compensated and all the industrial output will decline, although gradually, and this decline will progress at variable rates in accordance to their dependence on the supply of energy and raw materials. At the same time, the high inefficiency of the productive system will also lead to unsustainable levels of pollution, linking an environmental problem of large proportions to the foreseen (social) economic collapse. Is there really a basis for this catastrophic point of view? If so, is it possible to reverse the negative trend indicated by the "business as usual" model? Mining is a heavy industry positioned upstream of many productive chains so that less favourable signs (even faint) should be taken as serious future warnings.

The successive economic cycles that affected mining production over time were regulated by a large number of factors that also experienced significant variation in nature and relative weight. These economic cycles disturbed the demand/supply patterns of many industrial minerals and metals differently but did not modify the clear trend towards a generalized increase in production (using primary or secondary sources) to satisfy the growth in demand and consumption of a progressively more diverse number of raw materials. This evolution led to current models of sustainable economic growth which are metal-intensive and will not be successful in the future without ensuring a continuous supply of mineral-derived products (e.g. Angerer et al., 2009; Kleijn et al., 2011; Graedel, 2011; Mudd and Weng, 2012; Massari and Ruberti, 2013; Goe and Gaustad, 2014; Coulomb et al., 2015; Wellmer and Hagelüken, 2015; Blagoeva et al., 2016; Ali et al., 2017; Vidal et al., 2017; de Villiers, 2017). However, the concomitant track record of mineral exploration endeavours is not so auspicious, particularly throughout the last 15 years, raising some concerns about the maintenance of high production rates in the forthcoming years. In fact, according to Shodde (2010a, b, 2014a, b; 2017a, b): (i) the exploration expenditures reached an all-time high in 2012 ( $\approx 33$ US\$ billion), falling by $69 \%$ in the next four years; (ii) for the very first time, the intrinsic value of total findings since that peak did not surpass the investments made in their discovery and the best return rates took place in a short period of time (mostly between 2008 and 2010); (iii) the methodologies used to recognize resources below $500 \mathrm{~m}$ depth were more effective in brownfield than greenfield settings and, in addition, quite sensitive to the ore-system type; (iv) all the very deep discoveries were clustered in a few well-known mining districts; and (v) most of the reported discoveries were of poor quality, and only 12 first-class, high quality, deposits were recognized in the last decade. These data, along with supplementary information in Shodde (2010a, b, 2014a, b; 
2017a, b), clearly show that discoveries are being made (corroborating expectations stated in the previous section) but the quality of these discoveries is declining, particularly in terms of grade and costeffective access.

The less positive performance trend displayed by mineral exploration endeavours after the 2003-2012 boom intensifies the pressure on the mining industry, conceivably generating a cascade of problems that could lead to an outcome not much different from that predicted by the "business as usual" model. However, that pressure could be significantly minimized if new commitments between the industry, investors and academia were undertaken to develop different approaches (assuming clustering strategies as an important role) and funding structures aiming at new targets and the chance of expanding the number of high quality discoveries. It is well-known that declining finance for junior companies and reducing exploration budgets released by major companies have considerable impact on the success of mineral exploration projects. But, in this regard, regional and national administrations must also be aware of the foreseen risks triggered by a gradual freezing of mineral exploration endeavours. Thus, they should act together by assuming their share of responsibility in the support of far-reaching mineral exploration and mining development plans; it is indeed a matter of public importance/interest that is vital to the future success of sustainable economic growth programmes.

The search for high quality resources has always been a challenging task whose complexity and risk increase with the depth of the targets and the knowledge available about their settings. Continuous investments in brownfield surveys are important (e.g. Whiting and Shodde, 2006) but insufficient to achieve long-term goals of global mineral production. Therefore, they should be complemented with longrun exploration projects in new grassroots/greenfield areas using other concepts, suitable combinations of field work and various technologies, and affording significant drilling. Together and properly managed, all these endeavours will optimize exploration, generating innovative insights on: (i) conceptual metallogenic modelling through improvements of current knowledge about critical factors ruling the progression of ore-forming processes in different scales of space and time, including geothermochronology (e.g. Wyborn et al., 1994; Holliday and Cook, 2007; Hagemann et al., 2007; Benavides et al., 2008; Tassinari et al., 2008; 2015; Piercey, 2010; McCuaig et al., 2010; McCuaig and Hronsky, 2014; Hagemann et al., 2016; Huston et al., 2016; Smith et al., 2016; Groves et al., 2016; Codeço et al., 2018); (ii) distal manifestations of concealed ore systems by means of mineralogical and geochemical/isotopic criteria, which can also be used to discriminate targets with high metal contents and/or larger tonnage (e.g. Craig, 2001; Holk et al., 2003; Piché and Jébrak, 2004; Kelly et al., 2006; Kerrich and Wyman, 2007; Jackson, 2010; Cheng and Zhao, 2011; Dupuis and Beaudoin, 2011; Wang et al., 2012; Wilkinson et al., 2015; Zao et al., 2016; Champion and Huston, 2016; Dill, 2018; Gonçalves et al., 2018); (iii) combined data processing resulting from various geophysical methods and using inversion model techniques (e.g. Oldenburg et al., 2007; Laznicka, 2014; Inverno et al., 2015; Revuelta, 2018); and (v) joint analysis of physical properties and mineralogical/ geochemical data to better resolve potential targets (e.g. Laznicka, 2014).

At this point it should be emphasized that technological enhancements in regional property-scale tools, such as airborne IP, along with cross-usage developments of MT and seismic methods, will be critical to cover large grassroots/greenfield areas and resolve deeper structures and/or potential targets. Another important challenge directly impacting the success of exploration is drilling, especially in covered regions or when looking to depths below those typically identified by ordinary geophysical methods. Thus, methodological improvements are needed to reduce the operational costs with drilling, optimize the number of "directional drillings", and systematically collect more data (either via supplementary down-hole information on rock properties or real-time sampling and analysis at the drill-rig). Moreover, a deepened integration of whole-rock chemical analyses and isotopic data with conceptual models of oreforming processes is absolutely decisive to future achievements in mineral exploration. In this particular regard, besides the highly demanding QA/OC programmes, it is essential to quit the so-called "exploration detection limits" and move towards complete, research-level, multi-element geochemical datasets.

To sum up, one may ask how many high quality brownfield- and/or greenfield-located new discoveries would be necessary to suitably solve all the impending problems related to the future of mining production. That is a tricky and unfeasible question given the high number of inter-related factors involved in the appraisal of the economics of each resource, many of them also depending on specific market features, and all impossible to anticipate. But certainly, we should act preventively because the accessible number of these "hidden giants" is conceivably short and, usually, there is a long delay (10 to 20 years, on average) between the discovery and the exploitation beginning. 
Therefore, four important supplementary lines of action should be consolidated in the forthcoming years (Fig. 2). The first one relies on resources often classified as $2^{\text {nd }}$ class due to their smaller dimension, lower grades or higher complex mineral matrixes (potentially creating technical difficulties and expanding the costs in processing/beneficiation operations); these are more abundant than the "attractive" $1^{\text {st }}$ class, high quality, resources and a clever (integrated) approach to concerted regional small-scale mining assisted by common processing facilities, might have a noteworthy impact on the yearly totals produced for a wide range of mineral concentrates. The second line of action concerns the long-run availability of minor metals with growing importance in the ongoing technological (r)evolution; these form two main categories that reflect the joint or parallel production with major metals ensuring, respectively, the mining project profitability (co-products) or providing extra value to it but not influencing the optimal ore quantity produced (byproducts). The third line of action depends on the possibility of reassessing and exploiting some historical mining wastes, especially when they are not accumulated in places where evident signs of natural attenuation processes already exist; this could be particularly relevant for many metals commonly or exclusively obtained nowadays as co- or by-products but of hard (or impossible) extraction in the past due to technological limitations. The fourth line of action includes the gains gathered through the reduction of consumption along with all the ways promoting reuse, recycling and substitution; this is the basic support of the "urban and industrial resources" involved in circular economy models, quite insufficient per se to meet the foreseen increase in demand of industrial minerals and, most of all, metals. We will return to this subject in Section 6 after some words on the potential challenges posed by the criticality and sustainability concepts to the supply shortage analysis and to the mining/processing operations, respectively.

\section{Static and dynamic analysis of Criticality}

In recent times, implications related to threats of disruption in the supply of raw materials have been addressed by different criticality studies using sets of aggregated indicators variably weighed in accordance to specific aims (e.g. Humphreys, 1995; Cox, 2008; Erdmann and Graedel, 2011; Achzet and Helbig, 2013; Glösser et al., 2015; Graedel et al., 2015b; Graedel and Reck, 2015; Helbig et al., 2016; Dewulf et al., 2016; McCullough and Nassar, 2017; Frenzel et al., 2017). A simple inspection of these studies shows, however, that the assessments were based on distinct assumptions and static indicator-structures, sharing some features but deviating significantly in many others. The two main approaches were developed by the US National Research Council (e.g. NRC 2007; NSTC, 2016) and by the EU Commission (EU Commission 2010, 2014; Deloitte et al., 2017; Blenginia et al., 2017) both relying on a "criticality matrix" to appreciate the impact on the economy triggered by short- to longterm supply shortages in raw materials. A detailed discussion of these studies (their specific aims, methodological options, indicator structures and results) is beyond the scope of this paper. Nevertheless, the fact that several relevant inter-relationships to properly address the material criticality are missing or poorly accounted for should be emphasized, namely in what concerns: (i) the strong irregularity that typifies the production of many metals vital to key-technologies and for which the usual "market mechanisms" do not work [as is mostly the case of minor metals produced as by-products, not having a reliable production track record and being characterized by a price-inelastic behaviour]; (ii) the impact of mineral exploration results and of the overall costs related to the exploitation of resources of poorer quality and/or lower grade and/or higher deepness [representing a central issue in the analysis of forthcoming demand/supply balances that cannot be ignored or underestimated]; (iii) changes in market needs due to manufacturing adjustments of conventional products, emergence of new sectors generating distinct and competitive goods [effect of "common need"] and/or rates of economic growth over time [by using static indicators, only a "snapshot" of the criticality of a certain material in a particular timewindow is provided]; (iv) feedback between possible demand and supply chain developments, and their effects on the background systems on which these products and activities depend [static approaches implicitly assume that substitution decisions on the demand side only marginally affect the supply chain, which is not necessarily true]; and (v) the relative importance of environmental impacts because they might change considerably with the exploitation of lower ore grades and/or higher complex mineral matrices allowed by increases in demand [thus generating, at least potentially, greater disturbances in the mass flows ordinarily established between natural reservoirs].Therefore, as is clearly demonstrated in several studies (e.g. van Vuuren et al, 1999; Söderholm andTilton, 2012; Roelich et al., 2014; Habib and Wensel, 2016; Frenzel et al., 2017), new approaches are needed in criticality assessments not only to include the interactions of demand and supply 


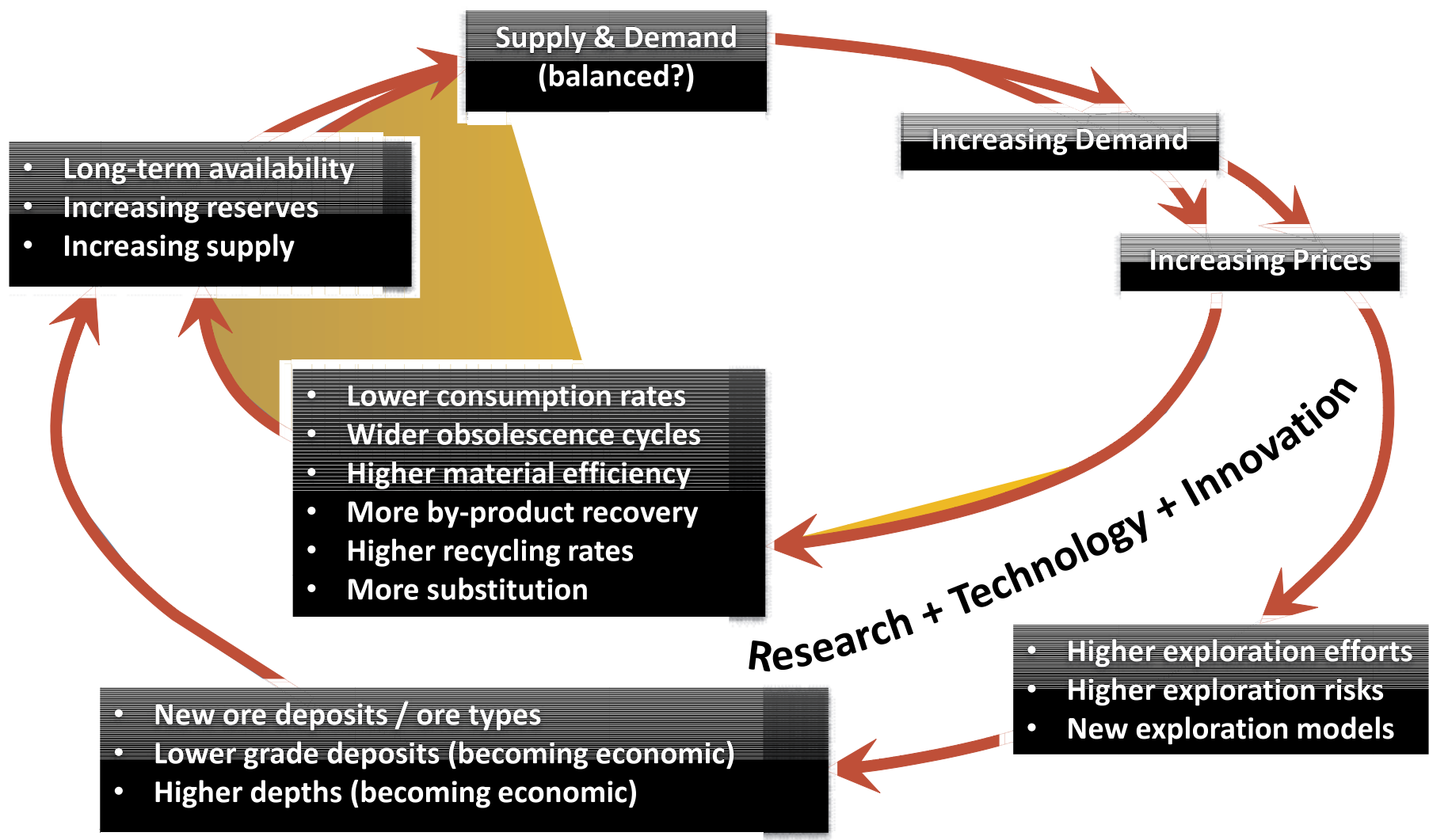

Figure 2. Forthcoming supply/demand balances are strongly dependent on technological trends for products that require an intensive use of raw materials; for instance, major developments in "clean technologies" (sustainable energy systems. hybrid/electric vehicles, energy storage, etc.) and communication/information systems (including smart grids) imply a considerable increase in metals consumption. The price of commodities is a main variable in the equation, usually subjected to economic cycles; in simple terms, the existing supply cannot meet fast enough a sudden increase in demand and the prices rise, especially when demand is inelastic (which happens in many supply chains). Therefore, two parallel pathways should proceed to suitably address these supply/demand unbalances of unpredictable magnitude and duration, both supported by intense research, technology and innovation. One of the pathways describes the advances needed to promote well-succeeded mineral exploration endeavours (when the prices keep high during an economic positive cycle, more investments are made in these surveys, but their effects are always delayed due to the high standby time needed for the mining development). Therefore, a judicious use of materials along with different secondary sources (second pathways), reduce the pressure on primary production and supply, compensating the growth in demand. Acting together, instead of compete for specific market shares, all the primary and secondary material sources will provide the means to ensure a long-term availability of the materials needed to support the ongoing technological (r)evolution. After Mateus (2017a).

Figura 2. Los futuros balances de oferta/demanda dependen en gran medida de las tendencias tecnológicas de productos que requieren un uso intensivo de materias primas; por ejemplo, los principales desarrollos en "tecnologías limpias" (sistemas de energía sostenible, vehículos híbridos/eléctricos, almacenamiento de energía, etc.) y sistemas de comunicación/información (incluidas redes inteligentes) implican un aumento considerable en el consumo de metales. El precio de las materias primas es una variable principal en la ecuación, generalmente sujeta a ciclos económicos; En términos simples, la oferta existente no puede satisfacer lo suficientemente rápido un aumento repentino de la demanda y los precios aumentan, especialmente cuando la demanda es inelástica (lo que ocurre en muchas cadenas de suministro). Por lo tanto, dos vías paralelas deberían proceder para abordar adecuadamente estos desequilibrios de oferta/demanda de magnitud y duración impredecibles, ambas respaldadas por una intensa investigación, tecnología e innovación. Una de las vías describe los avances necesarios para promover esfuerzos exitosos de exploración mineral (cuando los precios se mantienen altos durante un ciclo económico positivo, se realizan más inversiones en estos estudios, pero sus efectos siempre se retrasan debido al elevado tiempo de espera necesario para el desarrollo minero). Por lo tanto, un uso juicioso de materiales junto con diferentes fuentes secundarias (segundas vías), reduce la presión sobre la producción y el suministro primarios, compensando el crecimiento de la demanda. Actuando juntos, en lugar de competir por cuotas de mercado específicas, todas las fuentes de materiales primarias y secundarias proporcionarán los medios para garantizar una disponibilidad a largo plazo de los materiales necesarios para respaldar la (r)evolución tecnológica en curso. Después de Mateus (2017a).

parameters, but also to address their dynamic change over time, and the related environmental impact throughout the life cycle of the materials. Results based on static criticality assessments might be misleading and are certainly not enough to identify future constraints. Their usefulness to assist long-term deci- 
sions is therefore dubious, particularly when intensive investments needed to develop new mining facilities are under consideration, which is why the real impact of the available material criticality studies on mining industry management and planning was not as high as initially might have been envisaged.

Despite the limitations inherent to the static approaches used so far in assessments of material criticality, an upstream clarification should be done regarding the criticality concept itself. This is of upmost importance because it determines the way in which the impact of supply shortage or disruption will be weighed and modelled, i.e. the approach chosen to evaluate the resilience demonstrated by the socioeconomic system exposed to that threat and its ability to find in due time adequate responses to overcome the problem. And this is significant because supply shortages or disruptions can result from a large number of causes and also be mitigated by an equivalent number of alternatives, such as: (i) an unexpected increase in demand occurring at a time where the production level is close to its maximum capacity; (ii) technological or environmental restrictions hindering quick upsurges in production; (iii) socio-political interferences in the production planning or subsequent trading (e.g. instabilities in workforce or in fiscal policies, export quotas, etc.); (iv) market imbalances (strong fluctuations in currency exchange; volatility of prices; hegemonic producers); (v) dependence of by-products to the production of leading metals; (vi) availability and feasibility of recycling and substitutability to reduce primary demand; (vii) diversification of industrial needs by extending consumption to a wide range of metals; and (viii) reduction of the material intensity through improvements in the efficiency of manufacturing processes and by the widening of obsolescence cycles of the produced goods. So, material criticality is a dynamic property that captures both the possible supply shortages/disruptions in raw materials and the foreseen vulnerability of the socio-economic system to those disturbances that will determine production delays or under-achievements of societal goods or even environmental impacts of variable magnitude. Therefore, material criticality can be defined as a measure of the multiple consequences (not exclusively economic) arising from the expectation (possibility, contingency or likelihood) of that supply disruption occurring, which is often expressed as an insufficiency (or shortage) limited in time. Algebraically: $C=D x V$, where $C$ represents the material criticality, $D$ the expectation of an event of supply disruption, and $V$ the vulnerability of the system subjected to the effects triggered by that event (see also, Glösser et al., 2015; Frenzel et al.,
2017). The implications of this reasoning can be appraised through a simple exercise using the results of the most recent criticality assessment made by the EU and plotting them into a uniform matrix with contours of constant criticality (Fig. 3). This procedure provides a quite distinct picture from the one disclosed by the EU official report, showing that the great majority of the 78 raw materials assessed are below $C=40$; evident exceptions are $\mathrm{Dy}, \mathrm{Mg}, \mathrm{Sm}, \mathrm{Gd}$ and $\mathrm{Nd}$ by decreasing order of their global score. Another feature of interest is that materials with a similar criticality level (therefore plotting in contiguous $C$ curves) are differently classified as critical or non-critical in the EU study due to the inappropriate imposition of thresholds. Therefore, there seems to be no reason to worry. But, if so, why did the external dependence of the EU not stop growing, importing more and more metals and many industrial minerals every year? Which of the variables ( $D$ or $V$ were underestimated? Just the vulnerability of the European socio-economic system in the time window covered by the study? Or, was the expectation for a supply shortage/ disruption misjudged? Or, simply, both variables ( $D$ or $V$ were rightly evaluated but representing no more than a period of (very) slow economic growth in the EU during which the shares of recycling and substitution in global consumption were relatively high? These are questions that are difficult to answer but certainly not totally unrelated to the wide scope of the criticality assessment completed in the EU, along with the limited data availability for many of the selected raw materials and the choices made on particular metrics and the aggregation level of the indicators (Deloitte et al., 2017; Blenginia et al., 2017).

To conclude, criticality assessments are of little relevance for mining development unless improvements in dynamic modelling have been accomplished along with adequate harmonization (and enrichment) of the existent databases. However, some of the indicators used may offer reasonable indications of market trends, namely the relative importance of consumption by sub-sectors positioned downstream of mining production, as well as the geography of production (relatively hegemonic in market share and/or comparatively distributed in space).

\section{Challenges and opportunities related to sustainability}

The concept of sustainability has not been equally appreciated by all individual and institutional players, often leading to hasty measures and incongruent 

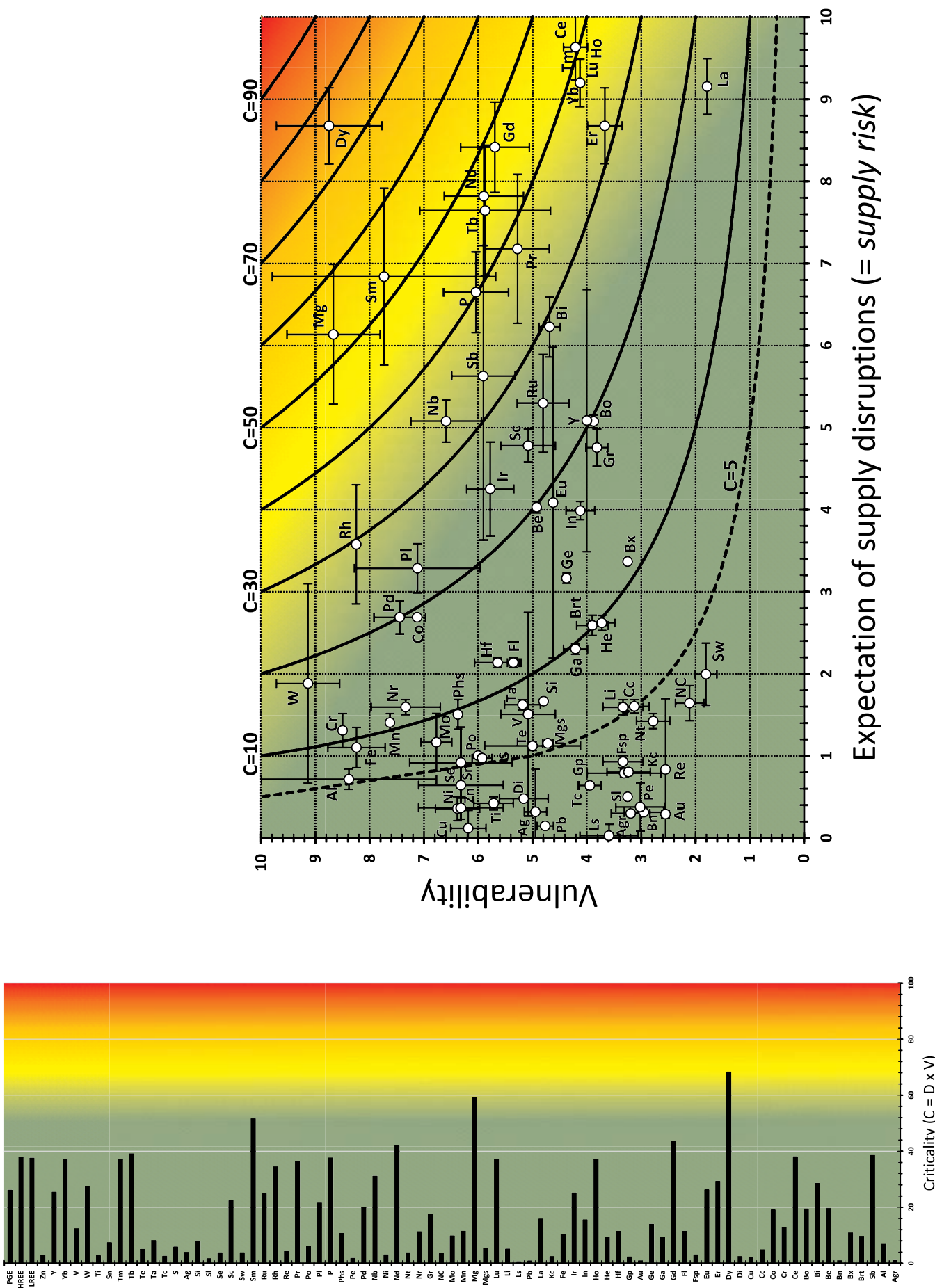
practices that hardly weigh up the long term consequences (e.g. Mawhinney, 2002; Graedel and Klee, 2002). In fact, some of these measures are designed on the basis of biased judgments about the environmental impact of some economic activities, many of them forming the primary sector of production. However, let us be clear: there is no sustainable development without wealth creation, and the latter will always depend on a healthy economy, which, in its turn, has heavy industry as the fundamental mainstay. There are certainly industrial practices that will have to change, following the general trend of modernization notably recorded in the last three decades; but there is also a need to clearly change the consumption patterns of society, particularly those that have become usual in developed economies. Therefore, as a concept, sustainability is no more than a comprehensive process of change that, at each stage of societal development, pursues the best balance between: (i) economic imperatives, efficiently managing natural resources and contributing to prosperity; (ii) environmental imperatives, not exceeding the natural supply capacity provided by eco-services and recovering degraded systems; and (iii) social imperatives, placing Humanity and ethical values in the sphere of concerns that should rule the progress. According to this wide perspective, the transition towards sustainable socio-economic growth models, including the circular economy paradigm (see section 6 ), is only just beginning and it is expected to continue for a considerable time period. During such a transition, conventional practices will be gradually replaced by others that are more efficient and technologically evolved, and innovative processes might also emerge leading to disruption of the "business as usual" behaviour. If successful, all these transformations will support a consolidated process of socioeconomic adjustments through which (i) the use of natural resources, (ii) the orientation of technological development, (iii) the channelling of investments, (iv) the evolution of (public and private) institutions, and (v) the principles ruling the consumption of society will become progressively harmonized with the constitution, organization and dynamics of natural systems, satisfying the needs of the current population and ensuring similar opportunities for forthcoming generations.

As far as what specifically concerns the mining industry, the challenges shaped around the concept of sustainability have been generating different opportunities for technological advancements and innovations in extractive and processing activities, also driving significant improvements for the engagement of local community (e.g. Humphreys, 2001;
Petrie, 2007; Shields, 1998; Mudd and Ward, 2008; Worrall et al., 2009; Mudd, 2010; Giurco and Cooper, 2012; Ali, 2014; Tilton and Guzmán, 2016; Revuelta, 2018). Many successful examples can be quoted in both lines of action but we must recognize that much still remains to be done; and this is the right time to irreversibly implement responsible mining practices (e.g. Goodland, 2012; Giurco et al., 2014) so that new projects and expanded operations cannot even dispute their need, particularly in relation to energy and water, which remain the most sensitive subjects for the large majority of regions. In this regard, recent lessons from circumstantial adjustments triggered by "market opportunities" should be taken as serious warnings for the future.

During the last mining boom and related high commodity prices, from ca. 2003 to 2012, new projects and expansions of active operations were quickly launched with an evident escalation of capital costs, often developing low-grade resources and running at lower cut-offs, respectively. The net result of such impulsive growth was a clear deterioration of quality in many mines in terms of grade, followed by an inevitable increase of strip ratios, tailings volumes, and energy and water consumption per unit of product; therefore, incidental responses to the market involved efficiency shortfalls in many cases. As prices declined considerably after 2012 all these factors impacted negatively on the operating costs and margins, putting the industry under considerable pressure once again and giving arguments to those who insist on the inability of mining to move away from the "business as usual" mentality, regardless of the consequences. Therefore, how should we deal with this problem, given the inevitability of accessing deeper and lower grade resources in the future? The combination of the latter two factors with increasing energy and cost intensity (per unit of product), environmental imperatives (e.g. water, dust and tailings management) and desirable efficiency gains, demands new technologies and, most of all, a new rational.

The issues related to production efficiency and operating costs are not new to the mining industry (e.g. Phillips et al., 1976; Gordon et al., 2006; Mason et al., 2011; Ali et al., 2017). Over time, these issues have been approached differently with relative success, although usually involving short-term measures. In fact, the historical track record reveals that consecutive enhancements in global production have been achieved at the expense of significant decreases in cut-off grades and the consequent generation of larger quantities of waste. The global production growth should continue for some time (even without a 
remarkable increase in the number of new $1^{\text {st }}$ class deposits and despite of prices volatility), coupled with a gradual declining in ore grades and a persistent rise in residues and wastes (although ever more linked to open pit mining). Thus, the identification of critical areas for improving efficiency, since the very beginning, of all the system components involved in mining and ore processing is of foremost importance (Fig. 4).

The intended endeavours should have as main aims the reduction of energy intensity and the adequate use of mining residues along with the correct disposal of residual wastes, without neglecting the health and safety of the workforce (e.g. Cowell et al.,
1999; Moran et al., 2014). However, as surprising as it may seem, the master key to the operationalization of the intended change in the mining industry is not the reengineering of the system and associated technological improvements, including robotics and cuttingedge methods of ore exploitation, treatment and beneficiation. All these advances are fundamental but without a far-reaching characterization of the ores and their host rocks we will hardly be able to evolve to higher levels of sustainability of the mining development. This characterization should be done at a scale fine enough to support optimization or evaluation of new approaches such as (e.g. Hilson and Basu, 2003; Norgat and Jahanshahi, 2010; Thompson, 2015;

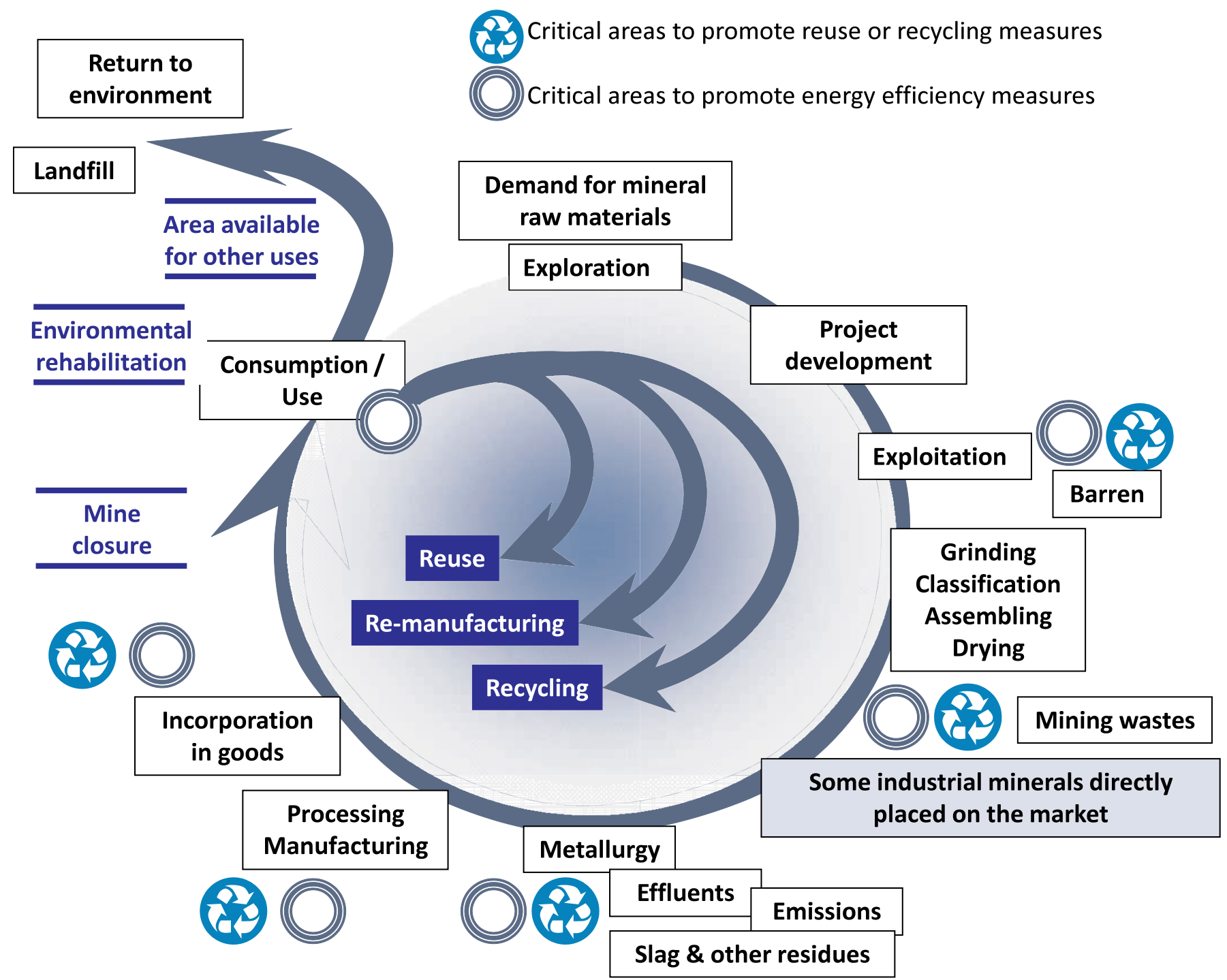

Figure 4. System re-engineering planning towards a responsible and sustainable mining development. Adapted from Suslick et al. (2005). Figura 4. Sistema de reingeniería de planificación hacia un desarrollo minero responsable y sostenible. Adaptado de Suslick et al. (2005). 
Brown et al., 2017): (i) studies of cost-effective blasting, making use of an extensive rock mechanics database (gathered from initial geotechnical assessments to subsequent blast hole-drilling) and aiming the production of suitably sized fragments for optimized "mine-to-mill" operations; (ii) complete (multi-scale) investigation of the ore-sites to enhance selectivity in mining, thus contributing to the volumetric reduction of rock waste and tailings; (iii) detailed analysis of grade variations and physical rock properties seeking for improvements in low-grade material separation at the face or through simple screening post-crushing by means of ore sorters in different stages of the flow sheet, reducing the energy consumption and boosting the efficiency of subsequent treatment processes; (iv) comprehensive inspection of the ore-forming phases to evaluate alternative methods (e.g. in situ leaching) to conventional, cost-intensive, mining and processing procedures, besides deep assessments on the possibility of gathering as many as possible mineral concentrates enriched in by-products; (v) thorough mineralogical studies along with technological advances to encourage and facilitate the generalization of "mine-to-metal" programmes that will allow upsurges in the supply value chain and the direct involvement of producers in the development of new products and recycling opportunities, contributing also to the gradual dismantling of the existent, heavy centralized grids of smelting and refining; and (vi) complete characterization of waste rocks and tailings to find, respectively, new ways for their use in downstream activities and novel approaches to their storage in distinct geological backgrounds subjected to different weathering conditions.

It is not possible to finalize this section without some words about the Social License to Operate (SLO) and Corporate Social Responsibility (CRS), whose foundations and implications have been widely debated in numerous studies (e.g. Jenkins and Yakovleva, 2006; Owen and Kemp, 2013; Owen, 2014; Moffat \& Zhang, 2014; Martín et al., 2014; Hall et al., 2015). Progress in these issues has been noteworthy, but much remains to be done in terms of effective reconciliation between decision-making criteria at the level of mining companies and the broader expectations of the population about the real contributions of this industrial activity to sustainable development. Significant deepening of dialogues amongst all stakeholders is needed to break down existing barriers (often grounded on suspicions and poorly informed opinions) and to understand, on a case-by-case basis, where the motivations of companies diverge from the aspirations of communities, thus preparing the pathways for subsequent fruitful interactions. This is the key-piece of the puzzle, closing the multifaceted circuit of sustainability where responsible mining operations should be placed, as is schematically illustrated in Figure 5.

\section{Circular economy models}

Despite the imprecision that is still involved in the concept of the circular economy (Kirchher et al., 2017; Korhonen et al., 2018), it does offer the possibility of reasonably integrating business development into sustainability aims (e.g. EU Commission, 2015; BIO by Deloitte, 2015). The main idea is overcome the current material and energy flow patterns (based on a continuous growth and increasing resource throughput) by a closing-the-loop pathway with a lower per-unit-production impact. Thus, the efficiency of resource use is accomplished through improvements in the reprocessing of urban and industrial waste by means of eco-design and recycling combined with reduction of consumption (e.g. George et al., 2015; Ghisellini et al., 2016; lacovidov et al., 2017). The idea is quite attractive, but there are a significant number of limitations and barriers to overcome (Ritzén and Sandström, 2017; Cooper et al., 2017); moreover, due to economic rebound effects, it appears that there is a limited ability for secondary products to be replaced by primary products at competitive prices (Zin and Geyer, 2017).

The implementation of (top-down or bottom-up) circular economy models is still in its infancy, mainly focused on recycling and less on preparation for reuse and consumption parsimony. And this happens because there is business and market (rightly built and/or politically supported) backing the process, putting secondary goods (resulting mostly from recycling) in direct competition with others produced from primary sources. However, the expected decrease in net production of primary goods and materials is not taking place as a result of this "market contest", demonstrating that interactions between primary and secondary goods are more difficult to predict than a simple engineering scheme would suggest. In the 1990s the European Commission tried to promote and establish the same kind of policies, but completely failed to do that. In the meanwhile the dependence of Europe on mineral raw materials increased dramatically. In fact, more than competing with each other, primary and secondary outputs should be envisaged as natural complements acting in a dynamic and highly demanding consumer market. So, much has to be done to fully incorporate the combined results in economy circular models from (i) 


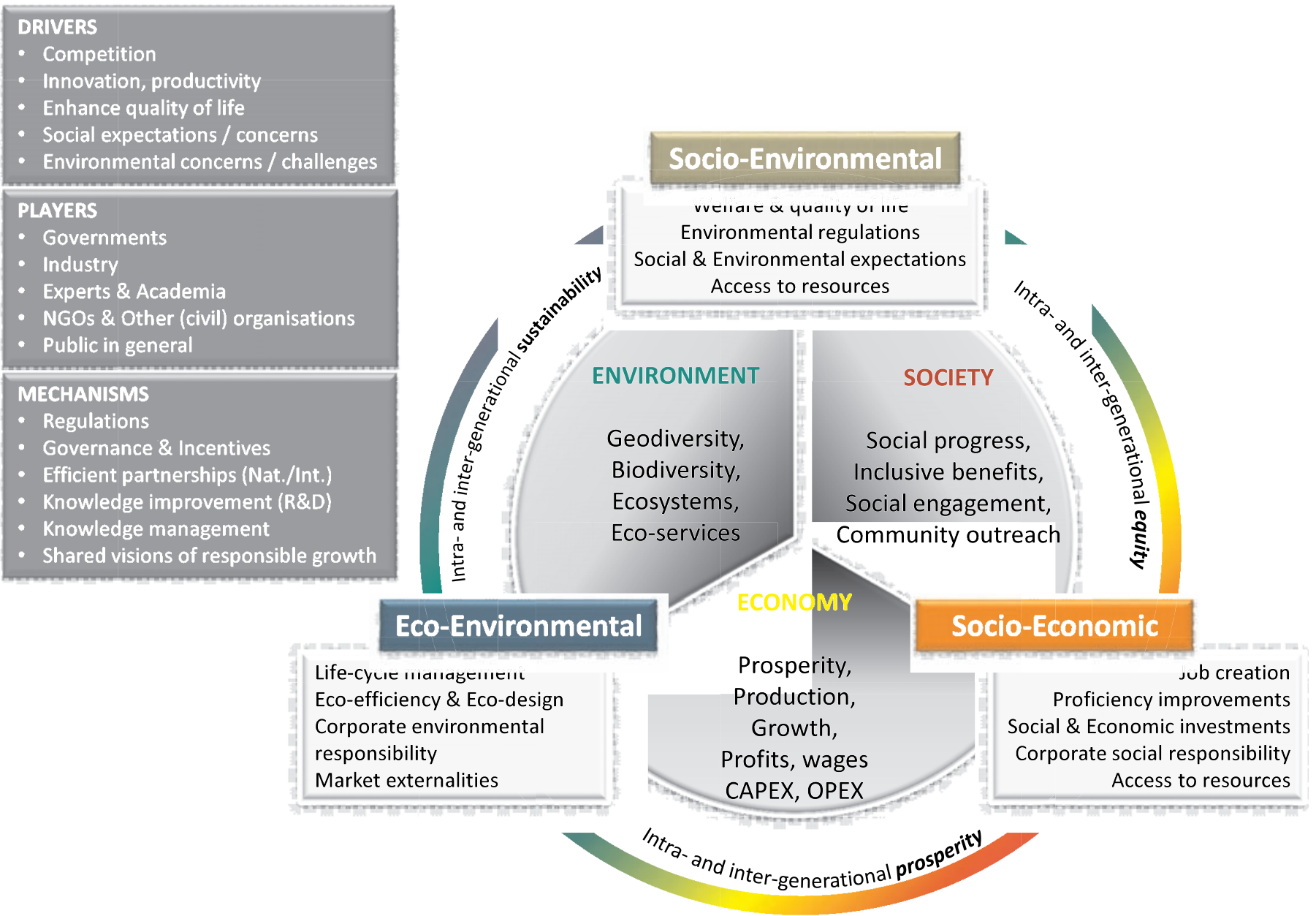

Figure 5. Fundamental elements for a responsible industrial activity. Modified from “Mining Sector Performance Report 1998-2012", Energy and Mines Ministers' Conference, August 2013, Canada.

Figura 5. Elementos fundamentales para una actividad industrial responsable. Modificado de la Conferencia de Ministros de Energía y Minas, agosto de 2013, Canadá.

degradation cycles of the components subject to recycling, (ii) obsolescence cycles of products and goods, and (iii) the contribution of substitutes when technologically and economically viable, and energetically efficient. Another important issue to look at in the future is the comprehensive characterization of raw material flows in different scales of the economic system. Often, proponents of the circular economy view the world as a model based on direct (and simple) flows between the consumer and the collector, and from the latter to the secondary processor, subsequently articulated with the manufacturer, and finally back to the consumer; the reality is not so simple as briefly addressed below for the case of metals and industrial minerals.

As aforementioned, we are facing an impressive set of challenges mostly related to the design of poli- cies and measures that will support, expectably, new models of sustainable economic growth. To a large extent, we have been living a transition period for a few years now that should extend for some more time. In the course of this transition period a significant change should take place in traditional (heavy, clustered) infrastructures, mentalities and governance. Concomitantly, if the main current political and economic drivers continue, and the foreseen technological megatrends are confirmed (involving the expansion of wind power, photovoltaics, carbon capture/sequestration, supercritical power plants, hybrid and electric transports, energy lighting efficiency, smart-grids, etc.), an increasing dependence on a large variety of metals and other industrial minerals will happen, boosting the chance of supply shortages or severe disruptions. And this will not 
affect only the so-called "critical metals" characterized by (so far) limited recycling, deficient knowledge of their resources/reserves (often exploited as byproducts), and quite often produced in a reduced number of countries and/or by a few companies. Possible supply shortages will also affect other strategic minerals, such as base metals and mineral raw materials involved in the manufacturing of many other products (different types of glass, cements, special steels and alloys, etc.) for which the relatively large and high grade easily accessible resources/reserves are declining (e.g. Vidal et al., $2013,2017)$; there are no evident substitutes for these materials, although their long-term recycling potential is high but with a major impact in terms of energy needs and in GHG emissions. In these circumstances, the implementation of adequate governance measures of mineral resources is crucial to ensure the long-term (sustainable) balance between the foreseen increase in demand and supply of metals and industrial minerals (e.g. Ali et al., 2017). Whilst these measures might differ considerably in "producing-" or "consuming-countries", they should globally reflect the services provided by mineral resources to society and, consequently, how they are ultimately valued (socially, technologically or economically). In addition, the requirements regarding a responsible sourcing of metals and industrial minerals (e.g. Wall et al., 2017) must be intensified, ensuring that commitments to sustainability are fulfilled worldwide. By combining these objectives with those set out in previous sections for mineral exploration and mining, it will be possible to maintain acceptable levels of medium- to long-term availability of primary resources. Considerable improvements in these pathways can still be expected in the presence of clear decreasing rates of consumption and enhanced contributions from recycling and reuse. Therefore, as in energy, the major challenge is to seek the mix of primary and secondary material sources that are appropriate to meet the needs of the present, keeping open all the possible solutions to better ensure the anticipated needs for the future. And these options cannot be prescribed universally because different mixings are valid in accordance to the current starting point and to the designed policies (and models) of development at regional, national and transnational levels. This is, in fact, the best way to properly use the resources available at each stage of development, generating the necessary wealth without which the convergence towards the sustainability aims would be impossible.

From the previous reasoning one may conclude that measures diversifying and globalising the supply chains through an improved and undistorted access to primary and secondary raw materials on world markets would be fundamental to ensuring stable supplies in future. However, we must realize that primary mineral resources will always remain as the backbone of these supply chains, because (e.g. Syverson, 2004; Johnson et al., 2007; Graedel et al., 2011; Reck and Graedel, 2012; Buijs et al., 2012): (i) total amounts of urban and industrial wastes forming diverse secondary sources are definitely insufficient to meet the current and future needs in raw materials; (ii) common dissipative applications and technically unfavourable metal compounds impose strong limitations on an efficient (and feasible) recovery; (iii) recycling rates depend on various (technological, energetic, economical) factors and will be continuously limited by the amounts coming back from society (i.e. what was consumed during the last decades), assuming that significant improvements in collecting systems will be achieved; and (iv) substitution options proceed usually under rates well below those imposed by market needs, thus many of them quickly become obsolete due to the advent of new materials or products, changes in customer needs or the generalization of successful recycling techniques.

\section{Concluding remarks}

A strong and competitive mining industry represents the backbone of any modern socio-economic cluster on raw materials. Therefore, the mining industry has to ensure its active involvement in ongoing decision processes and forward-looking discussions on future challenges, because only this role can constructively change biased judgments about exploration and exploitation activities, contributing in time with reconcilable solutions towards new models of sustainable economic growth. Additionally, this desirable interaction will create the adequate conditions to define and periodically assess the composition of the raw material mixings (involving primary mineral resources, recycling, substitution and reused components) needed to support the responsible socio-economic prosperity of a given community, region, country or any political form of transnational union or alliance.

No modern economy can achieve sustainable growth without an adequate and secure access to mineral resources, even in the presence of very effective reuse and recycling practices. The recent macroeconomic evolution of raw materials demonstrates that there is an increased need to diversify the supply of key-commodities through broadening the sources (therefore reducing the dramatic dependence of 
hegemonic producers) and making the markets more transparent. As a consequence, in recent decades, many large economies have developed mineral and metal strategies or approaches to avoid supply shortages/disruptions, mitigate challenges to their industrial sectors, and maximise economic opportunities. Equally relevant is the importance of environmental performance and the need to attain a social license to operate in order to successfully develop natural resources in a responsible way. In this regard, local communities, governments and international organizations are becoming more demanding and rigorous as far as exemplary practices, early social engagement and economic benefits are concerned.

The imminence of physical exhaustion of primary mineral resources is unlikely. The main difficulty resides in access (and conflicts with other land uses), political will and market dynamics. New geological targets for most metals will become deeper and lowgrade, requiring significant advances in mineral exploration, exploitation and processing techniques, along with an increasing social and environmental responsibility. Potential supply shortages or disruptions might affect not only metals used in the ongoing technological (r)evolution in the future. In this regard, criticality analysis based on static assessments might be misleading and cannot be used to support long-term decisions. On the contrary, the need for safeguarding the access to known deposits and promising targets should be considered as a firstorder priority and political decisions on this subject should be assisted by objective sets of criteria, incorporating exploration and mining planning into multiscale land use policies and corresponding territorial management tools.

A responsible development approach has become critical to gain competitive advantage in many countries, being essential to safeguard long-term investments and strengthen convenient partnerships, therefore avoiding discontinuity or disruption of mining projects. However, several issues with direct implications for the future planning of the mining industry remain unresolved satisfactorily, requiring innovative reasoning and cutting-edge (multidisciplinary) methodologies, as well as deeper commitments of national authorities to ascertain stable sectoral policies and additional support to exploration endeavours. In fact, integrated management of natural resources (necessarily including minerals) is a public requirement of prime importance and should be considered in administrative policy commitments along with specific funds to suitably accomplish this purpose. This also represents an important contribution to the needed global governance of mineral resources and the imposition of requirements regarding a responsible sourcing of metals and industrial minerals.

Mining is vital to economic recovery and inclusive growth, standing also as a mainstay of the so-called circular economy; it is also one of the few, large-scale economic activities that contributes to territorial cohesion, fixing the population and generating incomes directly impacting local communities. Nonetheless, the public in general tends to be suspicious about exploration/exploitation works and classifies the mining industry as very conservative and reluctant to change. This common perception, not entirely true, often relies on biased judgments that the industry has not been able to contradict satisfactorily. The promotion of new communication strategies along with transparent practices involving all the stakeholders from the initial stages of exploration surveys to the mining development, is crucial to modify the existent image of this ancient (but continuously renewed) industry and determine its long-term success.

\section{Acknowledgements}

A. Mateus acknowledges the financial support provided by FCT through the project UID/GEO/50019/2013.

\section{References}

Achzet B., Helbig C., 2013. How to evaluate raw material supply risks - an overview. Resources Policy, 38: 435447.

Ali S.H., 2014. Social and environmental impact of the rare earth industries. Resources, 3: 123-134.

Ali S.H., Giurco D., Arndt N., Nickless E., Brown G., Demetriades A., Durrheim R., Enriquez M.A., Kinnaird J., Littleboy A., Meinert L.D., Oberhänsli R., Salem J., Schodde R., Schneider G., Vidal O., Yakovleva N., 2017. Mineral supply for sustainable development requires resource governance. Nature, 543: 367-372.

Allington R., Bailey E., Demecheleer P., 2016. Applications of geoscience in land-use and mineral planning; the importance of an integrated approach. Geophysical Research Abstracts. Vol. 18, EGU General Assembly 2016.

Angerer G., Marscheider-Weidemann F., Lüllmann A., Erdmann L., Scharp M., Handke V., Marwede M., 2009. Raw materials for emerging technologies - the influence of sector-specific feed stock demand on future raw materials consumption in Material-Intensive Emerging Technologies. German Federal Ministry of Economics and Technology.

Arndt N.T., Ganino C., 2012. Metals and society: an introduction to economic geology. Springer, p 160. 
Arndt N.T., Fontboté L., Hedenquist J.W., Kesler S.E., Thompson J.F.H., Wood D.G., 2017. Future global mineral resources. Geochemical Perspectives, 6: 1-171.

Benavides J., Kyser T.K., Clark A.H., Stanley C., Oater C., 2008. Exploration guides for copper-rich iron oxide-copper-gold deposits in the Mantoverde area, northern Chile: the integration of host-rock molar element ratios and oxygen isotope compositions. Geochemistry: Exploration, Environment, Analysis, 8: 343-367.

BGS, 2015. Risk List 2015: An Updated Supply Risk Index for Chemical Elements or Element Groups which are of Economic Value. British Geological Survey, Nottingham, United Kingdom.

BIO by Deloitte, 2015. Study on data for a raw material system analysis: roadmap and test of the fully operational MSA for raw materials. Prep. Eur. Comm. DG GROW.

Blagoeva D., Aves Dias P., Marmier A., Pavel C., 2016. Assessment of potential bottlenecks along the materials supply chain for the future deployment of low-carbon energy and transport technologies in the EU. Wind power, photovoltaic and electric vehicles technologies, time frame: 2015-2030. European Commission, DG Joint Research Centre. (No. EUR 28192 EN, doi: http://dx.doi.org/10.2790/08169).

Blenginia G.A., Nussa P., Dewulfa J., Nitaa V., Peiròa L.T., Vidal-Legaza B. Latunussaa C., Mancinia L., Blagoevab D., Penningtona D., Pellegrinic M., Van Maerckev A., Solarc S., Groholc M., Ciupageaa C., 2017. EU methodology for critical raw materials assessment: policy needs and proposed solutions for incremental improvements. Resources Policy, 53: 12-19.

Bloodworth A., Gunn G., 2012. The future of the global minerals and metals sector: issues and challenges out to 2050. Géosciences, 15: 90-97.

Brown G.E., Hochella M.F.Jr., Calas G., 2017. Improving mitigation of the long-term legacy of mining activities: nano- and molecular-level concepts and methods. Elements, 13: 325-330.

Buchert M., Schüler D., Bleher D., 2009. Critical metals for future sustainable technologies and their recycling potential. United Nations Environment Programme, United Nations University, Paris.

Buijs B., Sievers H., Tercero Espinoza L.A., 2012. Limits to the critical raw materials approach. Waste Resources Management, 165: 201-208.

Calvo G., Mudd G., Valero A., Valero A., 2016. Decreasing ore grades in global metallic mining: a theoretical issue or a global reality. Resources, 36.

Champion D.C., Huston D.L., 2016. Radiogenic isotopes, ore deposits and metallogenic terranes: novel approaches and the mineral systems concept. Ore Geology Reviews, 76: 229-256.

Christmann P., 2018. Towards a more equitable use of mineral resources. Natural Resources Research, 27: 159-177.

Cheng Q., Zhao P., 2011. Singularity theories and methods for characterizing mineralization processes and mapping geo-anomalies for mineral deposit prediction. Geoscience Frontiers, 2: 67-79.

Codeço M.S., Mateus A., Figueiras J., Rodrigues P., Gonçalves L., 2018. Development of the Ervidel-Roxo and Figueirinha-Albernoa volcanic seuences in the Iberian Pyrite Belt, Portugal: metallogenic and geodynamic implications. Ore Geology Reviews, 98: 80-108.

Cook E., 1976. Limits to exploitation of nonrenewable resources. Science 191: 677-682.

Cooper S.J.C., Giesekam J., Hammond G.P., Norman J.B., Owen A., Rogers J.R., Scott K., 2017. Thermodynamic insights and assessment of the "circular econmy". Journal of Cleaner Production, 162: 1356-1367.

Coulomb R., Dietz S., Godunova M., Bligaard Nielsen T., 2015. Critical minerals today and in 2030 (OECD Environment Working Papers). Organisation for Economic Cooperation and Development, Paris.

Cowell R., Owens S., 1998. Suitable locations: equity and sustainability in the minerals planning process. Regional Studies 32, 797-811.

Cowell R., Murdoch J., 1999. Land use and the limits to (regional) governance: some lessons from planning for housing and minerals in England. International Journal of Urban and Regional Research 23, 654-669.

Cowell S.J., Wehrmeyer, Argust P.W., Roberston G.S., 1999. Sustainability and primary extraction industries: theories and practices. Resources Policy, 25: 277-286.

Cox L.A., 2008. What's wrong with risk matrices? Risk Analysis, 28: 497-512.

Craig J.R., 2001. Ore-mineral textures and the tales they tell. The Canadian Mineralogist, 39: 937-956.

Crowson P.C.F., 2011. Mineral reserves and future minerals availability. Mineral Economics, 24, 1-6.

De Boer M.A., Lammertsma K., 2013. Scarcity of rare earth elements Chem. Sus. Chem., 6: 2045-2055.

De Villers J.P.R., 2017. How to sustain mineral resources: beneficiation and mineral engineering opportunities. Elements, 13: 307-312.

Deloite Sustainability, BGS, BRGM,TNO, 2017. Study on the review of the list of critical raw materials. Criticality assessments. Final Report prepared for the European Commission, 93p.

Dewulf J., Blengini G.A., Pennington D., Nuss P., Nassar N.T., 2016. Criticality on the international scene: quo vadis? Resources Policy, 50: 169-176.

Dill G.G., 2018. Geology and chemistry of Variscan-type pegmatite systems (SE Germany) - with special reference to structural and chemical pattern recognition of felsic mobile components in the crust. Ore Geology Reviews, 92: 205-239.

Dupuis C., Beaudoin G., 2011. Discriminant diagrams for iron oxide trace element fingerprinting of mineral deposits. Mineralium Deposita, 46: 319-335.

Erdmann L., GraedelT.E., 2011. Criticality of non-fuel minerals: a review of major approaches and analyses Environ. Sci. Technol., 45: 7620-7630.

EU Commission, 2010. Critical Raw Materials for the EU. Report of the Ad-hoc Working Group on Defining Critical Raw Materials (Brussels: EU Commission).

EU Commission, 2014. Critical Raw Materials for the EU. Report of the Ad-Hoc Working Group on Defining Critical Raw Materials (Brussels: EU Commission).

EU Commission, 2015. Closing the Loop - An EU action plan 
for the Circular Economy. COM (2015) 614 Final (Brussels: EU Commission).

Evans D., Stephenson M., Shaw R., 2009). The present and future use of "land" below ground. Land Use Policy, 26: 302-316.

Fizaine F., 2013. By product production of minor metals: threat or opportunity for the development of clean technologies? The PV sector as an illustration. Resources Policy, 38: 373-383.

Fortier S.M., Thomas C.L., McCullough E.A., Tolcin A.C., 2018. Global trends in mineral commodities for advanced technologies. Natural Resources Research, 27: 191-200.

Frenzel M., Tolosana-Delgado R., Gutzmer J., 2015. Assessing the supply potential of high-tech metals-a general method. Resources Policy, 46: 45-58.

Frenzel M., Ketris M.P., Seifert T., Gutzmer J., 2016. On the current and future availability of gallium Resources Policy, 47: 38-50.

Frenzel M., Kullik J., Reuter M.A., Gutzmer J., 2017. Raw material 'criticality' - sense or nonsense? Journal of Physics. D: Applied Physics 50, doi:10.1088/13616463/aa5b64.

George D.A.R., Chi-ang B.L., Chen Y., 2015. A circular economy model of economic growth. Environmental Modelling \& Software, 73: 60-63.

Ghisellini P., Cialani C., Ulgiati S., 2016. A review on circular economy: the expected transition to a balanced interplay of environmental and economic systems. Journal of Cleaner Production, 114: 11-32.

Giurco D., Cooper C., 2012. Mining and sustainability: asking the right questions. Minerals and Engineering, 29: 312.

Giurco D., McLellan B., Franks D.M., Nansai, K., Prior, T., 2014. Responsible mineral and energy futures: views at nexus. Journal of Cleaner Production, 84: 322-338.

Gleich B., Achzet B., Mayer H., Rathgeber A., 2013. An empirical approach to determine specific weights of driving factors for the price of commodities - a contribution to the measurement of the economic scarcity of minerals and metals. Resources Policy, 38: 350-362.

Glöser S., Tercero Espinoza L., Grandenberger C., Faulstich M., 2015. Raw material criticality in the context of classical risk assessment. Resources Policy, 44: 35-46.

Godinho M.M., 1982. Relação entre recursos e abundância de elementos químicos na crusta continental. Instituto Nacional de Investigação Científica, Centro de Geociências da Universidade de Coimbra, 58 p.

Goe M., Gaustad G., 2014. Identifying critical materials for photovoltaics in the US: a multi-metric approach. Applied Energy, 123: 387-396.

Gonçalves M.A., Mateus A., Pinto F., Vieira R., 2018. Using multifractal modelling, singularity mapping, and geochemical indexes for targeting buried mineralization: application to the W-Sn Panasqueira ore-system. Journal of Geochemical Exploration, 189: 42-53.

Goodland R., 2002. Responsible mining: the key to profitable resource development. Sustainability, 4: 20992126.
Gordon, R.B., Bertram, M., Graedel, T.E. 2006. Metal stocks and sustainability. Proceedings of the National Academy USA, 103 (5), 1209-1214.

Govett G.J.S., Govett M.H., 1972. Mineral resource supplies and the limits of economic growth. Earth Sci. Reviews, 8: $275-290$.

Graedel T.E., 2011. On the future availability of the energy metals.

Graedel T.E., Allwood J., Birat J.-P., Buchert M., Hagelüken C., Reck B.K., Sibley S.F., Sonnemann G., 2011. What do we know about metal recycling rates? J. Ind. Ecol., 15: 355-366.

Graedel T.E., Barr R., Chandler C., Chase T., Choi J., Christoffersen L., Friedlander E., Henly C., Jun C., Nassar N.T., Schechner D., Warren S., Yang M., Zhu C., 2012. Methodology of metal criticality determination. Environment Science Technology, 46: 1063-1070.

Graedel T.E., Erdmann L., 2012. Will metal scarcity impede routine industrial use? MRS Bulletin, 37: 325-331.

Graedel T.E., Harper E.M., Nassar N.T., Reck B.K., 2015a. On the materials basis of modern society. Proc. Natl. Acad. Sci. U.S.A., 112: 6295-6300.

Graedel T.E., Harper E.M., Nassar N.T., Nuss P., Reck B.K., 2015b. Criticality of metals and metalloids. Proc. Natl. Acad. Sci., 4257-4262.

Graedel T.E., Klee R.J., 2002. Getting serious about sustainability. Environmental Science Technology, 6(4): 523-529.

Graedel T.E., Reck B.K., 2015. Six years of criticality assessments. What have we learned so far? J. Ind. Ecol., 20: 692-699.

Groves D.I., Goldfarb R.J., Santosh M., 2016. The conjunction of factors that lead to formation of giant gold provinces and deposits in non-arc settings. Geoscience Frontiers, 7: 303-341.

Gunn G., 2011. Mineral scarcity-a non-issue? British Geological Survey.

Habib K., Wenzel H., 2016. Reviewing resource criticality assessment from a dynamic and technology specific perspective - using the case of direct-drive wind turbines. J. Clean. Production, 112: 3852-3863.

Hagemann S., Dalstra H.I., Hodkiewicz P., Flis M., Thorne W., McCuaig C., 2007. Recent advances in BIF-related ore models and exploration strategies. In "Proceeding of Exploration 07: Fifth Decennial International Conference in Mineral Exploration", edited by B. Milkereit, 811-821.

Hall, N., Lacey, J., Carr-Cornish, S., and Dowd, A.-M., 2015. Social licence to operate: understanding how a concept has been translated into practice in energy industries. Journal of Cleaner Production, v. 86, 301-310.

Henckens M.L.C.M., Driessen P.P.J., Worrell E., 2014. Metal scarcity and sustainability, analysing the necessity to reduce the extraction of scarce metals. Resources, Conservation and Recycling, 93: 1-8.

Hilson G., Basu A.J., 2003. Devising indicators of sustainable development for the mining and minerals industry: an analysis of critical background issues. The International Journal of Sustainable Development \& World Ecology, 10: 319-331. 
Humphreys D., 1995. Whatever happened to security of supply? Minerals policy in the post-Cold War world. Resources Policy, 21: 91-97.

Hagemann S.G., Lisitsin V.A., Huston D.L., 2016. Mineral system analysis: Quo vadis. Ore Geology Reviews 76, 504-522.

Helbig C., Wietschel L., Thorenz A., Tuma A., 2016. How to evaluate raw material vulnerability - an overview. Resources Policy, 48: 13-24.

Holk G.J., KyserT.K., Chipley D., Hiatt E.E., Marlatt J., 2003. Mobile $\mathrm{Pb}$-isotopes in Proterozoic sedimentary basins as guides for exploration of uranium deposits. Journal of Geochemical Exploration, 80: 297-320.

Holliday J.R., Cooke D.R., 2007. Advances in geological models and exploration methods for copper \pm gold porphyry deposits. In "Proceeding of Exploration 07: Fifth Decennial International Conference in Mineral Exploration", edited by B. Milkereit, 791-809.

Humphreys D., 2001. Sustainable development: can mining afford it? Resources Policy, 27: 1-7.

Humphreys D., 2013. Long-run availability of mineral commodities. Mineral Economics, 26:1-11.

Huston D.L., Mernagh T.P., Hagemann S.G., Doublier M.P., Fiorentini M., Champion D.C., Jaques A.L., Czarnota K., Cayley R., Skirrow R., Bastrakov E., 2016. Tectono-metallogenic systems - The place of mineral systems within tectonic evolution, with an emphasis on Australian examples. Ore Geology Reviews, 76: 168-210.

lacovidov E., Velis C.A., Purnell P., Zwirner O., Brown A., Hahladakis J., Millward-Hopkins J., Williams P.T., 2017. Metrics for optimizing the multi-dimensional value of resources recovered from waste in a circular economy: a critical review. Journal of Cleaner Production, 166: 910938.

Inverno C., Rosa C., Matos J., Carvalho J., Castello-Branco J.M., Batista M.J., Granado I., Oliveira J.T., Araújo V., Pereira Z., Represas P., Solá A.R., Sousa P., 2015. Modelling of the Neves Corvo área. In: "3D, 4D and Predictive Modelling of Major Mineral Belts in Europe", P. Weihed (ed.), Mineral Resource Reviews: 231-261, DOI 10.1007/978-3-319-17428-0_11.

Jackson R.G., 2010. Application of 3D geochemistry to mineral exploration. Geochemistry: Exploration, Environment, Analysis, 10: 143-153.

Jenkins H., Yakovleva N., 2006. Corporate social responsibility of the mining industry: exploring trends in social and environmental disclosure. Journal of Cleaner Production, 14: 271-284.

Johnson J., Harper E.M., Lifset S., GraedelT.E., 2007. Dining at the Periodic Table: metal concentrations as they relate to recycling. Environmental Science and Technology, 41: 1759-1765.

Kavlak G., McNerney J., Jaffe R.L., Trancik J.E., 2015. Metals production requirements for rapid photovoltaics deployment. Energy Environ. Sci., 8: 1651-1659.

Kelly D.L., Kelly K.D., Coker W.B., Caughlin B., Dohaty M.E., 2006. Beyond the obvious limits of ore deposits: the use of mineralogical, geochemical, and biological features for the remote detection of mineralization. Economic Geology, 101: 729-752.
Kerrich R., Wyman D.A., 2007. Review of developments in trace-elements fingerprinting of geodynamic settings and their implications for mineral exploration. Journal of Earth Sciences, 44: 465-487.

Kirchher J., Reike D., Hekkert M., 2017. Conceptualizing the circular economy: an analysis of 114 definitions. Resources, Conservation \& Recycling, 127: 221-232.

Kleijn R., van der Voet e., Kramer G.J., van Oers L., van der Giesen C., 2011. Metal requirements of low-carbon power generation. Energy, 36: 5640-5648.

Korhonen J., Honkasalo A., Seppällä J., 2018. Circular economy: the concept and its limitations. Ecological Economics, 143: 37-46.

Krausmann F., Gringrich S., Eisenmenger N., Erb K.-H., Harberl H., Fisher-Kowalski M., 2009. Growth in global materials use, GDP and population during the $20^{\text {th }}$ century. Ecological Economics, 68: 2696-2705.

Lazwcka P., 2014. Giant metallic deposits - a century of progresso. Ore Geology Reviews, 62: 259-314.

Lopes C., Lisboa V., Carvalho J., Mateus A., Martins L., 2018. Challenges to access and safeguard mineral resources for society: a case study of kaolin in Portugal. Land Use Policy, 79, 263-284.

Lovik A.N., Restrepo E., Müller D.B., 2016. Byproduct metal availability constrained by dynamics of carrier metal cycle: the gallium-aluminum example. Environ. Sci. Technol., 50: 8453-8461.

Lusty P.A., Gunn A.G., 2014. Challenges to global mineral resource security and options for future supply. In: Jenkin, G. R. T., Lusty, P. A. J.,McDonald, I., Smith, M. P., Boyce, A. J. \& Wilkinson, J. J. (eds) Ore Deposits in an Evolving Earth. Geological Society, London, Special Publications, 393.

McCuaig, T.C., Beresford, S., Hronsky, J., 2010. Translating the mineral systems approach into an effective exploration targeting system. Ore Geol. Rev. 38, 128-138.

McCuaig, T.C., Hronsky, J.M.A., 2014. The mineral system concept: the key to exploration targeting. Soc. Econ. Geol. Spec. Publ. 18, 153-176.

Mason L., Prior T., Mudd G., Giurco D., 2011. Availability, addiction and alternatives: three criteria for assessing the impact of peak minerals on society. Journal of Cleaner Production, 19: 958-966.

Massari S., Ruberti M., 2013. Rare earth elements as critical raw materials: focus on international markets and future strategies. Resources Policy, 38: 36-43.

Mateus A., 2016. Overview of the mining and geological potential: challenges for the future (CRM). Portugal International Mining Business \& Investment Summit, 12-14 April, Lisbon, Portugal.

Mateus A., 2017a. Recursos globais de lítio; situação actual e perspectivas futuras. Seminário DEGGE, Faculdade de Ciências, Universidade de Lisboa, 23 Março, Portugal.

Mateus A., 2017b. The relevance of primary mineral resources in circular economy models. Encontro Ciência'17, 3-5 Julho, Lisboa, Portugal.

Mateus, A., Lopes, C., Martins, L., Carvalho, J., 2017. Towards a multi-dimensional methodology supporting a safeguarding decision on the future access to mineral resources. Mineral Economics, 30: 229-255. 
Martín A.R., Díaz M.R., Román, S.R., 2014. Measure of the mining image. Resources Policy 41, 23-30.

Mason L., Prior T., Mudd G., Giurco D., 2011. Availability, addiction and alternatives: three criteria for assessing the impact of peak minerals on society. Journal of Cleaner Production, 19: 958-966.

Mawhinney M., 2002. Sustainable development. Understanding the green debates. Blackwell Publishing, $190 \mathrm{p}$.

Meadows, D.H., Meadows, D.L., Randers, J., and Behrens, W., III. 1972. The Limits to Growth. Universe Books, New York, 205 p.

Menaker G.I., 1978. Theoretical trace-element distributions for igneous rocks. Int. Geol. Rev., 23: 96-104.

McCullough E., Nassar N.T., 2017. Assessment of critical minerals: updated application of an early-warning screening methodology. Mineral Economics, 30: 257272.

Meinert L.D., Robinson G.R.Jr., Nassar N.T., 2016. Mineral resources: reserves, peak production and the future. Resources, 5: 14. doi:10.3390/resources5010014.

Moffat, K. and A. Zhang, 2014. The paths to social licence to operate: An integrative model explaining community acceptance of mining. Resources Policy 39: 61-70.

Moran C.J., Lodhie S., Kunz N.C., Huisingh D., 2014. Sustainability in mining, minerals and energy: new processes, pathways and human interactions for a cautiously optimistic future. Journal of Cleaner Production, 84: 1-5.

Moss R.L., Tzimas E., Willis P. et al., 2013. Critical metals in the path towards the decarbonisation of the EU energy sector. European Commission Joint Research Centre Institute for Energy and Transport, Luxembourg.

Mudd G.M., 2007a. An analysis of historic production trends in Australian base metal mining. Ore Geology Reviews, 32: 227-261

Mudd G.M., 2007b. Global trends in gold mining: towards quantifying environmental and resource sustainability. Resources Policy, 32: 42-56.

Mudd G.M., 2010. The environmental sustainability of mining in Australia: key mega-trends and looming constraints. Resources Policy, 35: 98-115.

Mudd G.M., Jowitt S., 2018. Global resource assessments of primary metals: an optimistic reality check. Natural Resources Research 27, 229-240.

Mudd G.M., Jowitt S.M., Werner T.T., 2017. The world's leadzinc mineral resources: scarcity, data, issues and opportunities. Ore Geology Reviews 80, 1160-1190.

Mudd G.M., Ward, J.D., 2008. Will sustainability constraints cause "peak minerals"? In: 3rd International Conference on Sustainability Engineering and Science: Blueprints for Sustainable Infrastructure. Auckland, New Zealand.

Mudd, G.M., and Weng, Z. 2012. Base metals. In: Letcher, T.M., and Scott, J.L. (eds.), Materials for a Sustainable Future. Royal Society of Chemistry, Cambridge, UK, 11-59.

Mudd G.M., Weng Z., Jowitt S. M., Turnbull I.D., GraedelT.E., 2013. Quantifying the recoverable resources of by-product metals: The case of cobalt. Ore Geology Reviews 55, 87-98.
Nassar N.T., Graedel T.E., Harper E.M., 2015. By-product metals are technologically essential but have problematic supply. Science Advances, 1(3).

Norgate T., Jahanshahi S., 2010. Low grade ore-smelt, leach or concentrate? Minerals Engineering, 23: 65-73.

Northey S.A., Mudd G.M., Werner T.T., 2018. Unresolved complexity in assessments of mineral resource depletion and availability. Natural Resources Research 27, 241255.

NRC 2007 Minerals, Critical Minerals, and the US Economy (Washington, DC: The National Academies Press).

NSTC 2016 Assessment of Critical Minerals: Screening methodology and initial application. Product of the Subcommittee on Critical Strategic Mineral Supply Chains of the Committee on Environment, Natural Resources, and Sustainability (Washington, DC: National Science and Technology Council).

Oldenburg D.W., Pratt D.A., 2007. Geophysical inversion for mineral exploration: a decade of progress in theory and practice. In "Proceeding of Exploration 07: Fifth Decennial International Conference in Mineral Exploration", edited by B. Milkereit, 61-95.

Owen J.R., Kemp D., 2013. Social licence and mining: a critical perspective. Resources Policy, 38: 29-35.

Owen J.R., Kemp D., 2014. Free prior and informed consent', social complexity and the mining industry: Establishing a knowledge base: Resources Policy, v. 41, 91-100.

Owens S., 1997. Interpreting Sustainable Development. The case of land use planning. The Political Quarterly 69, Wiley Online Library.

Patiño-Douce, A.E., 2016. Metallic mineral resources in the twenty-first century. I. Historical extraction trends and expected demand. Natural Resources Research, 25: 71-90.

Petrie J., 2007. New models of sustainability for the resources sector. A focus on minerals and metals. Trans. IChemE, Part B, 85: 88-98.

Phillips W.G.B., Edwards D.P., 1976. Metal prices as a function of ore grade. Resources Policy, 2: 167-178.

Piché M., Jébrak M., 2004. Normative minerals and alteration ondexes developed for mineral exploration. Journal of Geochemical Exploration, 82: 59-77.

Piercey S.J., 2010. An overview of petrochemistry in the regional exploration for volcanogenic massive sulphide (VMS) deposits. Geochemistry: Exploration, Environment, Analysis, 10: 1-18.

Prior, T., Giurco, D., Mudd, G.M., Mason, L., 2012. Resource depletion, peak minerals and the implications for sustainable resource management. Global Environmental Change 22, 577-587.

Reck B.K., Graedel T.E., 2012. Challenges in metal recycling. Science, 337: 690-695.

Revuelta M.B., 2018. Mineral resources; from exploration to sustainability assessment. Springer Textbooks in Earth Sciences, Geography and Environment. Springer International Publishing AG, 653 p.

Ritzén S., Sandström G.Ö, 2017. Barriers to the circular economy - integration of perspectives and domains. Procedia CIRP, 64: 7-12. 
Roelich K., Dawson D.A., Purnell P. et al., 2014. Assessing the dynamic material criticality of infrastructure transitions: a case of low carbon electricity. Applied Energy, 123: 378-386.

Rosenau-Tornow D., Buchholz P., Riemann A., Wagner M., 2009. Assessing the long-term supply risks for mineral raw materials - a combined evaluation of past and future trends. Resources Policy 34: 161-175.

Rudnick R.L., Gao S., 2014. Composition of the continental crust. In: Holland, H.D. \& Turekian, K. K. (eds) Treatise on Geochemistry $2^{\text {nd }}$ Edition. Elsevier, Vol. 4: 1-52.

Shields D.J., 1998. Nowrenewable resources in Economic, Social, and Environmental Sustainability. Nonrenewable Resources, 7: 251-261.

Shodde R., 2010a. The declining discovery rate -what is the real story? AMIRA International's 8th Exploration Managers Conference 22-23 March 2010, Yarra Valley, Victoria.

Shodde R., 2010b. Global discovery trends 1950-2009: What, where and who found them. PDAC 2010, 7 March 2010, Toronto.

Schodde R., 2012. Global mineral exploration trends. China Mining Conference $3^{\text {rd }}-6^{\text {th }}$ November, Tianjin, China.

Shodde R., 2014a. Uncovering exploration trends and the future: where's exploration going? International Mining and Resources (IMARC) Conference, 22th September 2014 Melbourne, Australia.

Shodde R., 2014b. The Global Shift to Undercover Exploration - How fast? How effective? Society of Economic Geologists 2014 Conference 30th September 2014, Keystone, Colorado, USA.

Shodde R., 2017a. Recent Trends and Outlook for Global Exploration. PDAC 2017 6th March 2017, Toronto, Canada.

Schodde R., 2017b. Time delay between discovery and development - is it getting more difficult? China Mining Conference $23^{r d}$ September 2017, Tianjin, China.

Shodde R., 2017c. Long term trends in global exploration are we finding enough metal? $11^{\text {th }}$ Fennoscandian Exploration and Mining Conference 31st October 2017, Levi, Finland.

Skinner B.J., 1976. A second iron age ahead? Am. Scientist, 64: 258-269.

Smith M.P., Moore K., Kavecsánszki D., Finch A.A., Kynicky J., Wall J., 2016. From mantle to critical zone: a review of large giant sized deposits of rare earth elements. Geoscience Frontiers, 7: 315-334.

Söderholm P., Tilton J.E., 2012. Material efficiency: an economic perspective. Resources, Conservation and Recycling, 61: 75-82.

Suslick S.B., Machado I.F., Ferreira D.F., 2005. Recursos minerais e sustentabilidade. Campinas, SP, Editora Komedi, Brasil, 246 p.

Sverdrup H., Ragnasdóttir, K.A., 2014. Natural resources in a planetary perspective. Geochemical Perspectives, 3: 129-341.

Syverson C., 2004. Product substitutability and productivity dispersion. Review of Economics and Statistics, 86: 534550.

Tassinari C.C.G., Mateus A.M., Velásquez M.E., Munhá
J.M.U., Lobato L.M., Bello R.M., Chiquini A.P., Campos W.F., 2015. Geochronology and thermochronology of gold mineralization in the Turmalina deposit, NE of the Quadrilátero Ferrífero region, Brazil. Ore Geology Reviews, 67: 368-381.

Tassinari C.C.G., Pinzon F.D., Ventura J.B., 2008. Age and sources of gold mineralization in the Marmato mining district, NW Colombia: a Miocene-Pliocene epizonal gold deposit. Ore Geology Reviews, 33: 505-518.

Thompson J.F.H., 2015. New approaches to familiar practices are critical for long-term success. Australian IMM Bulletin, Opinion, June 2015 (online access).

Tilton J.E., 2003. On borrowed time? Assessing the threat of mineral depletion. Resources for the Future, Washington DC, USA.

Tilton J.E., 2006. Depletion and the long-run availability of mineral commodities. In: Doggett, M.E., and Parry, J.R. (eds.), Wealth Creation in the Minerals Industry: Integrating Science, Business, and Education: Special Publication 12. Society of Economic Geologists, Littleton, CO, 61-70.

Tilton J.E., Crowson P.C.F., DeYoung J.H., Eggert R.G.Jr., Ericsson M., Guzmán J.I., Humphreys D., Lagos G., Maxwell P., Radetzki M., Singer D.A., Wellmer F.-W., 2018. Public policy and future mineral supplies. Resources Policy (https://doi.org/10.1016/j.resourpol.2018.01.006. Accessed March 2018).

Tilton J.E., and Guzmán J.I. 2016. Mineral Economics and Policy. Routledge for RFF Press, New York, 255 p.

Turner G., 2008. A comparison of The Limits of Growth with thirty years of reality. CSIRO Working Paper Series 20082009, 49 p.

Turner G., 2012. On the cusp of global collapse? Updated comparison of The Limits of Growth with Historical data. Gaia 1/2: 116-124.

Turner G., 2014. Is global collapse imminent? MSSI Research Paper $\mathrm{n}^{\circ}$ 4. Melbourne Sustainable Society Institute, the University of Melbourne, $22 \mathrm{p}$.

US Geological Survey, 2009. Mineral Commodity Summaries 2009. US Geological Survey, Reston, VA.

Van Vuuren D.P., Strengers B.J., de Vries H.J.M., 1999. Long term perspectives on world metal use - a systemdynamics model. Resources Policy, 25: 239-255.

Vidal O., Goffé B., Arndt N., 2013. Metals for a low-carbon society. Nature Geosciences, 6: 894-896.

Vidal O., Roston F., François C., Giraud G., 2017. Global trends in mineral consumption and supply: the raw material-energy nexus. Elements, 13: 319-324.

Yaksic A., Tilton J.E., 2009. Using the cumulative availability curve to assess the threat of mineral depletion: the case of lithium. Resources Policy, 34:185-194.

Wall F., Rollat A., Pell R.S., 2017. Responsible sourcing of critical metals. Elements, 13: 313-318.

Wang G., Carranza E.J., Zuo R., HaoY., DuY., Pang Z., Sun Y., Qu J., 2012. Mapping of district-scale potential targets using fractal methods. Journal of Geochemical Exploration, 122: 34-46.

Wellmer F.-W., Hagelüken C., 2015. The feedback control cycle of mineral supply, increase of raw material efficiency, and sustainable development. Minerals, 5 (4) 
Whiting T.H., Shodde R.C., 2006. Why do brownfields exploration? International Mine Management Conference $16^{\text {th }}$ $-18^{\text {th }}$ October 2006, Melbourne, Australia.

Wilkinson J.J., Chang Z.C., Cooke D.R., Baker M.J., Wilkinson C.C., Inglis S., Chen H., Gemmell J.B., 2015. The chlorite proximitor: a new tool for detecting porphyry ore deposits. Journal of Geochemical Exploration, 152: 10-26.

Worrall R., Neil D., Brereton D., Mulligan D., 2009. Towards a sustainable criteria and indicators framework for legacy mine land. Journal of Cleaner Production, 17: 14261434.
Wrighton, C. E., Bee, E. J., and Mankelow, J. M., 2014. The development and implementation of mineral safeguarding policies at national and local levels in the United Kingdom: Resources Policy, v. 41, 160-170.

Wyborn, L.A.I., Heinrich, C.A., Jaques, A.L., 1994. Australian Proterozoic mineral systems: essential ingredients and mappable criteria. AusIMM Publ. Ser. 5 (94), 109-115.

Zao R., Carranza E.J., Wang J., 2016. Spatial analysis and visualization of exploration geochemical data. EarthScience Reviews, 158: 9-18.

Zink T., Geyer R., 2017. Circular economy rebound. Journal of Industrial Ecology, 21: 593-602.

Recibido: diciembre 2017

Revisado: febrero 2018

Aceptado: junio 2018

Publicado: marzo 2019 
